\title{
SISTEM PERADILAN DI INDONESIA BERDASARKAN UUD NEGARA REPUBLIK INDONESIA TAHUN 1945
}

\author{
Ihat Subihat \\ Universitas Wiralodra \\ Email : Ihat_s2001@yahoo.com
}

\begin{abstract}
A country's judicial system cannot be separated from the legal system in force in the country. In other words, a country's justice system is a sub-system of the country's justice system. Because the legal system that applies in Indonesia is a legal system based on the Pancasila and the 1945 constitution of the Republic of Indonesia, the judicial system in Indonesia must also be based on Pancasila values and articles in the 1945 Constitution of the Republic of Indonesia. This study was conducted by using normative juridical method by reviewing various legal materials; primary, secondary and tertiary legal materials. While the data collection method was carried out through library studies. The analysis technique used descriptive method with prescriptive approach. The result of this study showed that the four judicial environments are under the Indonesia Supreme Court; general justice, religious justice, military justice and state administrative courts, as subjudicial systems in Indonesia, each of which has an institutional, authority and legal structure separate events that differ from one another according to the specificity and absolute competence of each that cannot be mixed up. In contrast to other judicial environments which have adjusted to the changes in the new judicial power law, the institutional structure and authority of the courts within the military court which is part of the judicial system under the Supreme court of the Republic of Indonesia is still regulated in Law Number 31 of 1997 concerning Military justice and not yet adjusted to Lay Number 14 of 2004 concerning Judicial Power, because the Amendment Draft to the Law on Military Justice which had been discussed since 2005 has not yet been agreed upon by the DPR and the Government. Even when the Lay on Military Justice cannot be adjusted to Law Number 4 of 2004, on October 29, 2009 Law Number 4 of 2004 was revoked and then replaced with Law Number 48 of 2009 concerning the latest Judicial Power.
\end{abstract}

Keywords: Justice System, 1945 Constitution, Judicial Power

\section{PENDAHULUAN}

Menurut Bagir Manan, ${ }^{67}$ sistem peradilan dapat ditinjau dari beberapa segi, yaitu: Pertama, sistem peradilan diartikan sebagai segala sesuatu yang berkenaan dengan penyelenggaraan peradilan. Disini, sistem peradilan akan mencakup kelembagaan, sumber daya, tata cara, prasarana dan sarana, dan lain-lain; Kedua, sistem peradilan diartikan sebagai proses mengadili (memeriksa dan memutus perkara).

\footnotetext{
${ }^{67}$ Bagir Manan, Sistem Peradilan Berwibawa (Suatu Pencarian), Mahkamah Agung RI, Jakarta, 2007, hal.17.
} 
Sistem peradilan suatu negara tidak dapat dilepaskan dari sistem hukum yang berlaku di negara tersebut. Dengan kata lain, sistem peradilan suatu negara merupakan sub sistem dari sistem hukum negara tersebut. Oleh karena sistem hukum yang berlaku di Indonesia adalah sistem hukum yang berdasarkan Pancasila dan UUD Negara RI Tahun 1945, maka sistem peradilan di Indonesia juga harus didasarkan pada nilai-nilai Pancasila dan pasal-pasal yang ada dalam UUD Negara RI Tahun 1945.

Berdasarkan Pasal 24 ayat (2) UUD Negara RI Tahun 1945 (hasil Amandemen Ketiga Tahun 2001) ditentukan bahwa: "Kekuasaan kehakiman dilakukan oleh sebuah Mahkamah Agung dan badan peradilan yang berada di bawahnya dalam lingkungan peradilan umum, lingkungan peradilan agama, lingkungan peradilan militer, lingkungan peradilan tata usaha negara; dan oleh sebuah Mahkamah Konstitusi”.

Sebagai penjabaran Pasal 24 UUD Negara RI Tahun 1945, maka ditetapkanlah UU Nomor 4 Tahun 2004 tentang Kekuasaan Kehakiman yang menggantikan UU Nomor 14 tahun 1970 tentang Ketentuan-Ketentuan Pokok Kekuasaan Kehakiman, dan UU Nomor 5 tahun 2004 tentang Perubahan Atas UU Nomor 14 Tahun 1985 Tentang Mahkamah Agung, serta UU Nomor 24 Tahun 2003 tentang Mahkamah Konstitusi.

Berdasarkan Pasal 24 C UUD Negara RI Tahun 1945 dan UU Nomor 24 tahun 2003 tentang Mahkamah Konstitusi, ditentukan bahwa Mahkamah Konstitusi merupakan pengadilan negara setingkat dengan Mahkamah Agung yang mempunyai kewenangan mengadili pada tingkat pertama dan terakhir (yang putusannya bersifat final) untuk: menguji undang-undang terhadap UUD; memutus sengketa kewenangan lembaga negara yang kewenangannya diberikan oleh UUD; memutus pembubaran partai politik, dan memutus perselisihan tentang hasil Pemilu.

Sedangkan mengenai struktur kelembagaan peradilan di bawah Mahkamah Agung dapat dibedakan antara susunan horizontal dan susunan vertikal. Susunan horizontal menyangkut berbagai lingkungan badan peradilan seperti tersebut dalam Pasal 24 ayat (2) UUD Negara RI Tahun 1945, yaitu: peradilan umum, peradilan agama, peradilan militer, dan peradilan tata usaha negara. Selain itu ada juga badan-badan peradilan khusus yang berada di lingkungan peradilan umum, dan juga mahkamah syar'iah yang berada di lingkungan peradilan agama. Keempat lingkungan peradilan di bawah Mahkamah Agung tersebut masing-masing memiliki struktur tersendiri yang semuanya bermuara pada Mahkamah Agung sebagai pengadilan negara yang tertinggi. Susunan vertikal terdiri dari: pengadilan tingkat pertama dan pengadilan tingkat banding yang ada pada keempat 
lingkungan peradilan, serta pengadilan tingkat kasasi yang ada pada Mahkamah Agung sebagai muara dari keempat lingkungan peradilan di bawahnya.

Mengenai pembinaan organisasi, administrasi, dan finansial kekuasaan kehakiman, dalam Pasal 13 UU Nomor 4 Tahun 2004 tentang Kekuasaan Kehakiman ditentukan bahwa:

"(1) Organisasi, administrasi, dan finansial Mahkamah Agung dan badan peradilan yang berada di bawahnya berada di bawah kekuasaan Mahkamah Agung.

(2) Organisasi, administrasi, dan finansial Mahkamah Konstitusi berada di bawah kekuasaan dan kewenangan Mahkamah Konstitusi.

(3) Ketentuan mengenai organisasi, administrasi, dan finansial badan peradilan sebagaimana dimaksud pada ayat (1) untuk masing-masing lingkungan peradilan diatur dalam undang-undang sesuai dengan kekhususan lingkungan peradilan masing-masing."

Berdasarkan ketentuan tersebut di atas dapat diartikan bahwa keempat lingkungan peradilan di bawah Mahkamah Agung, yaitu: peradilan umum, peradilan agama, peradilan militer, dan peradilan tata usaha negara, masing-masing mempunyai kekhususan dalam melaksanakan tugas dan kewenangannya di bidang peradilan, sehingga oleh karenanya masing-masing lingkungan peradilan di bawah Mahkamah Agung diatur dengan undangundang tersendiri, yang tentunya harus mengacu pada UU Nomor 4 Tahun 2004 sebagai undang-undang induk yang mengatur tentang sistem peradilan di Indonesia yang telah disesuaikan dengan UUD Negara RI Tahun 1945. Dalam perkembangannya, pada tanggal 29 Oktober 2009 UU Nomor 4 Tahun 2004 dicabut dan kemudian diganti dengan UU Nomor 48 Tahun 2009 tentang Kekuasaan Kehakiman.

Mengenai kewenangan badan peradilan di bawah Mahkamah Agung RI, sebagaimana yang ditentukan dalam Pasal 25 UU Nomor 48 Tahun 2009 adalah sebagai berikut :

"a. Peradilan umum berwenang memeriksa, mengadili, dan memutus perkara pidana dan perdata sesuai dengan ketentuan peraturan perundang-undangan.

b. Peradilan agama berwenang memeriksa, mengadili, memutus, dan menyelesaikan perkara antara orang-orang yang beragama Islam sesuai dengan ketentuan peraturan perundang-undangan.

c. Peradilan militer berwenang memeriksa, mengadili, dan memutus perkara tindak pidana militer sesuai dengan ketentuan peraturan perundang-undangan.

d. Peradilan tata usaha negara berwenang memeriksa, mengadili, memutus, dan menyelesaikan sengketa tata usaha negara sesuai dengan ketentuan peraturan perundang-undangan." 
Kewenangan peradilan umum, peradilan agama, dan peradilan tata usaha negara yang disebutkan dalam Pasal 25 UU Nomor 48 Tahun 2009 pada dasarnya sama dan tidak mengalami perubahan jika dibanding dengan undang-undang sebelumnya yang mengatur tentang kekuasaan kehakiman. Namun mengenai kewenangan peradilan militer mengalami perubahan yang signifikan, yaitu dari yang sebelumnya peradilan militer berwenang memeriksa, mengadili, dan memutus perkara 'tindak pidana' (umum maupun militer) yang dilakukan prajurit atau yang dipersamakan dengan prajurit, maka dalam UU Nomor 48 Tahun 2009 diubah menjadi hanya berwenang memeriksa, mengadili, dan memutus perkara 'tindak pidana militer' saja.

Untuk memberi gambaran yang lebih lengkap mengenai sistem peradilan di Indonesia, berikut ini akan diuraikan mengenai sistem peradilan di Indonesia, yang diartikan sebagai sesuatu yang berkenaan dengan penyelenggaraan peradilan yang mencakup kelembagaan dan kewenangan masing-masing lingkungan peradilan di bawah Mahkamah Agung RI sebagai sub-sub sistem peradilan di Indonesia, serta proses penyelesaian perkara pidana di lingkungan peradilan umum dan di lingkungan peradilan militer.

\section{METODE}

Spesifikasi penelitian ini adalah deskriptif analitis, dengan pendekatan Yuridis Normatif, yaitu penelitian yang bertujuan menggambarkan mengenai fakta-fakta disertai analisis yang akurat mengenai peraturan perundang-undangan penelitian yang menitikberatkan pembahasan pada data-data sekunder berupa bahan-bahan hukum, baik primer, sekunder maupun tersier, yang didukung data primer.

Teknik pengumpulan data dilakukan melalui Penelitian kepustakaan yakni untuk memperoleh bahan-bahan hukum baik primer, sekunder, maupun tersier. ${ }^{68}$ Bahan hukum primer adalah bahan-bahan yang berasal dari peraturan perundang-undangan, antara lain UUD 1945, UU Nomor 48 Tahun 2009 tentang Kekuasaan Kehakiman, UU Nomor 5 tahun 2004 tentang Perubahan Atas UU Nomor 14 Tahun 1985 Tentang Mahkamah Agung, serta UU Nomor 24 Tahun 2003 tentang Mahkamah Konstitusi.

Bahan-bahan hukum sekunder berkaitan dengan bahan-bahan hukum yang menjelaskan peraturan perundang-undangan, yakni RUU Industri Pertahanan, Doktrin, dan

\footnotetext{
${ }^{68}$ Sunaryati Hartono, Penelitian Hukum di Indonesia Pada Akhir Abad ke-20, Alumni, Bandung, 1994, hlm. 134.
} 
lain-lain. Sedangkan bahan hukum tersier berupa tulisan-tulisan dari jurnal, majalah, media social, dan lain-lain. Teknis Analisis data yang digunakan dalam penelitian ini adalah deskriptif analisis normatif, yakni pemaparan dan penggambaran peraturan perundang-undangan secara kualitatif.

\section{PEMBAHASAN}

\subsection{Sub Sistem Peradilan Umum}

\subsubsection{Struktur Kelembagaan Dan Kewenangan}

Struktur kelembagaan dan kewenangan pengadilan di lingkungan peradilan umum yang merupakan bagian dari sistem peradilan di bawah Mahkamah Agung RI diatur dalam UU Nomor 2 Tahun 1986 tentang Peradilan Umum, yang diubah dengan UU Nomor 8 Tahun 2004, dan kemudian diubah lagi dengan UU Nomor 49 Tahun 2009 tentang Perubahan Kedua Atas UU Nomor 2 Tahun 1986 Tentang Peradilan Umum.

Sesuai Pasal 2 UU Nomor 8 Tahun 2004 jo UU Nomor 49 Tahun 2009, Peradilan Umum berwenang memeriksa dan mengadili perkara perdata dan perkara pidana bagi rakyat pencari keadilan pada umumnya. Untuk melaksanakan kewenangannya tersebut, peradilan umum membagi wilayah hukum sesuai dengan tingkatan pengadilan, yaitu:

- Pengadilan Negeri, sebagai pengadilan tingkat pertama, berkedudukan di ibukota Kabupaten/Kota, dan daerah hukumnya meliputi wilayah Kabupaten/ Kota;

- Pengadilan Tinggi, sebagai pengadilan tingkat banding berkedudukan di ibukota Provinsi, dan daerah hukumnya meliputi wilayah Provinsi.

Dalam perkembangannya, selain mempunyai wewenang penyelesaian perkara perdata dan pidana yang bersifat umum, sesuai ketentuan Pasal 8 UU Nomor 49 Tahun 2009 dan penjelasannya, di pengadilan dalam lingkungan peradilan umum dapat dibentuk pengadilan khusus, misalnya pengadilan anak, pengadilan niaga, pengadilan hak asasi manusia, pengadilan tindak pidana korupsi, pengadilan hubungan industrial, dan pengadilan perikanan.

Pada saat ini telah ada beberapa pengadilan khusus di lingkungan peradilan umum, yaitu: Pengadilan Niaga (pada PN Jakarta Pusat, PN Medan, PN Semarang, PN Surabaya, dan PN Makasar), Pengadilan HAM (PN Jakpus, PN Medan, PN Surabaya, dan PN Makasar), Pengadilan Tipikor (ada di setiap PN ibukota Propinsi), Pengadilan Hubungan Industrial, Pengadilan Anak, dan Pengadilan Perikanan. 
Sebagai sub sistem peradilan, yang salah satu kewenangannya adalah menyelenggarakan peradilan pidana, penyelenggaraan peradilan pidana di peradilan umum harus memperhatikan konsepsi "Integrated Criminal Justice System" atau Sistem Peradilan Pidana Yang Terintegrasi. Dalam konsepsi "Integrated Criminal Justice System", penyelenggaraan peradilan pidana merupakan wujud interaksi penegakan hukum yang melibatkan berbagai komponen aparat penegak hukum sebagai sub sistem, yaitu: Penyidik, Penuntut Umum, Pengadilan, dan Lembaga Pemasyarakatan. Dengan proses peradilan pidana yang seperti itu, kinerja masing-masing komponen aparat penegak hukum merupakan satu cakupan atau rangkaian yang berada di dalam komplek manajemen peradilan pidana, yang tidak hanya ditentukan oleh proses penyelesaian perkara pidana di pengadilan, tetapi juga meliputi proses penyelesaian perkara sejak seseorang tersangka dilakukan penyelidikan, penyidikan, penuntutan, pemeriksaan dan pemutusan perkaranya di pengadilan, dan juga proses pelaksanaan pidananya di Lembaga Pemasyarakatan. ${ }^{69}$

\section{1.2. Proses Penyelesaian Perkara Pidana di Peradilan Umum}

Hukum acara yang digunakan untuk menyelesaikan perkara pidana di lingkungan peradilan umum adalah UU Nomor 8 Tahun 1981 tentang Kitab Undang-Undang Hukum Acara Pidana (KUHAP) dan beberapa undang-undang baru yang didalamnya juga mengatur tentang ketentuan-ketentuan khusus, seperti UU Kejaksaan, UU Bea Cukai, UU Keimigrasian, UU Tipikor, dan sebagainya.

Sesuai KUHAP sebagai undang-undang inti yang mengatur acara pidana di lingkungan peradilan umum, proses penyelesaian perkara pidana di lingkungan peradilan umum dilaksanakan melalui tahap-tahap yang pada pokoknya sebagai berikut :

\section{1) Tahap Penyelidikan.}

Sesuai Pasal 1 angka 5 KUHAP, yang dimaksud dengan "penyelidikan" adalah serangkaian tindakan penyelidik untuk mencari dan menemukan suatu peristiwa yang diduga sebagai tindak pidana guna menentukan dapat atau tidaknya dilakukan penyidikan menurut cara yang diatur dalam KUHAP. Yang bertindak sebagai 'penyelidik' dalam KUHAP adalah setiap pejabat Polri.

\footnotetext{
${ }^{69}$ Djoko Sarwoko, Perlindungan HAM Bagi Terdakwa Dalam Proses Persidangan, dalam Mahkamah Agung RI, Kapita Selekta Hak Asasi Manusia, Mahkamah Agung RI, Jakarta, 2002, hal.231-232.
} 
Sehubungan dengan tugas dan kewajibannya tersebut, sesuai Pasal 5 KUHAP, Penyelidik berwenang :

"a) Menerima laporan atau pengaduan dari seseorang tentang adanya tindak pidana;

b) Mencari keterangan dan barang bukti;

c) Menyuruh berhenti seseorang yang dicurigai dan menanyakan serta memeriksa tanda pengenal diri;

d) Mengadakan tindakan lain menurut hukum yang bertanggung jawab;

e) Atas perintah penyidik dapat melakukan tindakan berupa :

(1) Penangkapan, larangan meninggalkan tempat, penggeledahan dan penyitaan;

(2) Pemeriksaan dan penyitaan surat;

(3) Mengambil sidik jari dan memotret seseorang;

(4) Membawa dan menghadapkan seseorang pada penyidik."

Atas pelaksanaan tugas dan wewenangnya tersebut, Penyelidik membuat dan menyampaikan laporan hasil pelaksanaan penyelidikan kepada Penyidik.

\section{2) Tahap Penyidikan}

Sesuai Pasal 1 angka 2 KUHAP, yang dimaksud dengan "penyidikan" adalah serangkaian tindakan penyidik dalam hal dan menurut cara yang diatur dalam KUHAP untuk mencari serta mengumpulkan bukti yang dengan bukti itu membuat terang tentang tindak pidana yang terjadi dan guna menemukan tersangkanya. Yang bertindak sebagai 'penyidik' dalam KUHAP adalah Pejabat Polri dan Pejabat PNS tertentu yang diberi wewenang khusus oleh undang-undang. Sesuai ketentuan Pasal 106 KUHAP, penyidik yang mengetahui, menerima laporan atau pengaduan tentang terjadinya suatu peristiwa yang patut diduga merupakan tindak pidana wajib segera melakukan tindakan penyidikan yang diperlukan.

Sehubungan dengan tugas dan kewajibannya tersebut, sesuai Pasal 7 KUHAP, Penyidik berwenang :

"a) Menerima laporan atau pengaduan dari seorang tentang adanya tindak pidana;

b) Melakukan tindakan pertama pada saat di tempat kejadian;

c) Menyuruh berhenti seorang tersangka dan memeriksa tanda pengenal diri tersangka;

d) Melakukan penangkapan, penahanan, penggeledahan, dan penyitaan;

e) Melakukan pemeriksaan dan penyitaan surat;

f) Mengambil sidik jari dan memotret seseorang;

g) Memanggil orang untuk didengar dan diperiksa sebagai tersangka atau saksi;

h) Mendatangkan orang ahli yang diperlukan dalam hubungannya dengan pemeriksaan perkara;

i) Mengadakan penghentian penyidikan; 
j) Mengadakan tindakan lain menurut hukum yang bertanggung-jawab.”

Atas pelaksanaan tugas dan wewenangnya tersebut, penyidik membuat berita acara sesuai jenis tindakan yang dilakukan, dan kemudian disusun dalam bentuk berkas perkara guna diserahkan kepada penuntut umum untuk dilimpahkan ke pengadilan negeri.

Dalam melaksanakan tugas dan kewajibannya tersebut, penyidik diberi wewenang untuk menahan seseorang tersangka yang diduga telah melakukan tindak pidana yang diancam dengan pidana penjara lima tahun atau lebih, dan dikhawatirkan seseorang tersangka tersebut akan melarikan diri, merusak atau menghilangkan barang bukti, dan/atau mengulangi tindak pidana. Wewenang penahanan yang ada pada penyidik hanya berlaku paling lama 20 (dua puluh) hari, yang jika diperlukan untuk kepentingan pemeriksaan yang belum selesai dapat diperpanjang oleh penuntut umum yang berwenang untuk waktu paling lama 40 (empat puluh) hari. Penahanan tersebut dapat berupa: penahanan rumah tahanan negara, penahanan rumah, atau penahanan kota. Setelah waktu enam puluh hari terlampaui, penyidik harus mengeluarkan tersangka dari tahanan demi hukum. ${ }^{70}$

\section{3) Tahap Penuntutan}

Sesuai Pasal 1 angka 7 KUHAP, yang dimaksud dengan "penuntutan" adalah tindakan penuntut umum untuk melimpahkan perkara pidana ke pengadilan negeri yang berwenang dalam hal dan menurut cara yang diatur dalam KUHAP dengan permintaan supaya diperiksa dan diputus oleh hakim di sidang pengadilan. Penuntut umum adalah jaksa yang diberi wewenang oleh KUHAP untuk melakukan penuntutan perkara tindak pidana yang terjadi dalam daerah hukumnya, dan melaksanakan penetapan hakim.

Sehubungan dengan tugas dan tanggung-jawabnya tersebut, sesuai Pasal 14 KUHAP, penuntut umum berwenang :

"a) Menerima dan memeriksa berkas perkara penyidikan dari penyidik atau penyidik pembantu;

b) Mengadakan prapenuntutan apabila ada kekurangan pada penyidikan dengan memperhatikan ketentuan Pasal 110 ayat (3) dan ayat (4), dengan memberi petunjuk dalam rangka penyempurnaan penyidikan dari penyidik;

c) Memberikan perpanjangan penahanan, melakukan penahanan atau penahanan lanjutan dan/atau mengubah status tahanan setelah perkaranya dilimpahkan oleh penyidik;

d) Membuat surat dakwaan;

e) Melimpahkan perkara ke pengadilan;

\footnotetext{
${ }^{70}$ Disarikan dari ketentuan Pasal 20 sampai dengan Pasal 24 KUHAP
} 
f) Menyampaikan pemberitahuan kepada terdakwa tentang ketentuan hari dan waktu perkara disidangkan yang disertai surat panggilan, baik kepada terdakwa maupun kepada saksi, untuk datang pada sidang yang telah ditentukan;

g) Melakukan penuntutan;

h) Menutup perkara demi kepentingan hukum;

i) Mengadakan tindakan lain dalam lingkup tugas dan tanggung jawab sebagai penuntut umum menurut ketentuan undang-undang;

j) Melaksanakan penetapan hakim.

Setelah menerima hasil penyidikan dari penyidik, penuntut umum segera mempelajari dan meneliti kelengkapan berkas perkara. Dalam hal hasil penyidikan ternyata belum lengkap, penuntut umum mengembalikan berkas perkara kepada penyidik disertai petunjuk tentang hal yang harus dilakukan untuk dilengkapi, dan dalam waktu empat belas hari penyidik harus sudah menyampaikan kembali berkas perkara tersebut kepada penuntut umum. Dalam hal berkas perkara pidana telah lengkap dan memenuhi syarat untuk dilakukan penuntutan, penuntut umum membuat surat dakwaan, dan selanjutnya segera melimpahkan perkara tersebut ke pengadilan negeri yang berwenang dengan permintaan agar segera mengadili perkara tersebut disertai dengan surat dakwaan. $^{71}$

Dalam melaksanakan tugas dan tanggung-jawabnya tersebut, penuntut umum diberi wewenang melakukan penahanan atau penahanan lanjutan terhadap terdakwa/tersangka yang diduga telah melakukan tindak pidana yang diancam dengan pidana penjara lima tahun atau lebih, dan dikhawatirkan seseorang terdakwa/tersangka tersebut akan melarikan diri, merusak atau menghilangkan barang bukti, dan/atau mengulangi tindak pidana. Penahanan tersebut dapat berupa: penahanan rumah tahanan negara, penahanan rumah, atau penahanan kota untuk waktu paling lama 20 (dua puluh) hari. Jika waktu selama dua puluh hari tersebut tidak cukup, untuk kepentingan pemeriksaan yang belum selesai, masa penahanan terhadap terdakwa dapat diperpanjang oleh Ketua Pengadilan Negeri yang berwenang untuk waktu paling lama 30 (tiga puluh) hari. Setelah waktu 50 (lima puluh) hari terlampaui, terdakwa harus dikeluarkan dari tahanan demi hukum. ${ }^{72}$

\section{4) Tahap Pemeriksaan di Sidang Pengadilan}

\footnotetext{
${ }^{71}$ Disarikan dari ketentuan Pasal 137 sampai dengan Pasal 144 KUHAP.

72 Disarikan dari ketentuan Pasal 20 sampai dengan Pasal 25 KUHAP
} 
Setelah menerima surat pelimpahan perkara pidana dari penuntut umum, Ketua Pengadilan Negeri mempelajari apakah perkara itu termasuk wewenang pengadilan yang dipimpinnya. Dalam hal perkara tersebut termasuk wewenang pengadilan negeri yang dipimpinnya, Ketua Pengadilan Negeri menunjuk hakim yang akan menyidangkan perkara tersebut, dan hakim yang ditunjuk itu menetapkan hari sidang untuk memeriksa dan mengadili perkara pidana yang telah siap untuk disidangkan.

Menurut KUHAP ada empat jenis acara pemeriksaan perkara pidana di pengadilan negeri, yaitu: acara pemeriksaan biasa, acara pemeriksaan koneksitas, acara pemeriksaan singkat, dan acara pemeriksaan cepat. Perbedaan tata cara pemeriksaan tersebut didasarkan pada pertimbangan: berat atau ringannya ancaman hukuman atas tindak pidana yang dilakukan terdakwa, dan mudah atau sulitnya pembuktian perkara pidana yang akan disidangkan.

a) Acara pemeriksaan biasa.

Yang dimaksud "acara pemeriksaan biasa" adalah proses pemeriksaan perkara pidana di pengadilan yang dilaksanakan secara biasa, yaitu dengan tatacara pemeriksaan sebagaimana yang ditentukan undang-undang, dihadiri oleh penuntut umum dan terdakwa, dengan pembacaan surat dakwaan oleh penuntut umum. Demikian juga mengenai pembuktian dan alat bukti yang dipergunakan harus berpedoman pada ketentuan yang telah digariskan oleh undang-undang. ${ }^{73}$

Dalam KUHAP, ketentuan mengenai proses penyelesaian perkara pidana dengan acara pemeriksaan biasa diatur dalam Bab XVI, Bagian Ketiga dan Keempat, Pasal 152 s/d 202 KUHAP. Acara pemeriksaan biasa juga disebut sebagai pemeriksaan perkara 'dengan surat dakwaan'. Pemeriksaan perkara dengan memakai surat dakwaan inilah yang membedakan perkara yang diperiksa dengan acara pemeriksaan biasa dengan perkara lain yang diperiksa dengan "acara pemeriksaan singkat" atau "acara pemeriksaan cepat".

Ditinjau dari segi pengaturan dan kepentingannya, acara pemeriksaan biasa yang paling utama dan paling luas pengaturannya. Hal ini didasarkan pada kenyataan bahwa dalam acara pemeriksaan biasa inilah dilakukan pemeriksaan perkara-perkara tindak pidana kejahatan berat, sehingga fokus pengaturan acara pemeriksaan pada umumnya terletak pada ketentuan-ketentuan yang diatur dalam pasal-pasal acara pemeriksaan biasa. Perkara tindak pidana yang sifatnya tidak sederhana, ancaman hukumannya 5 tahun atau

73 M. Yahya Harahap, Pembahasan Permasalahan dan Penerapan KUHAP, Pemeriksaan Sidang Pengadilan, Banding, Kasasi, dan Peninjauan Kembali, Edisi Kedua, Cetakan Kesembilan, Sinar Grafika, Jakarta, Oktober 2007, hal.109 
lebih, pembuktian dan penerapan hukumnya tidak mudah, dan memerlukan pemeriksaan yang seksama dan cermat, pada umumnya diperiksa dengan acara pemeriksaan biasa. Sedang perkara yang ancaman hukumannya ringan, dan pembuktian tindak pidananya dinilai mudah, biasanya diperiksa dengan acara pemeriksaan singkat.

\section{b) Acara pemeriksaan koneksitas.}

Acara pemeriksaan koneksitas digunakan untuk memeriksa dan mengadili perkara tindak pidana koneksitas, yaitu tindak pidana yang dilakukan secara bersama-sama oleh mereka yang termasuk lingkungan peradilan umum dan lingkungan peradilan militer. Sesuai ketentuan Pasal 22 UU Nomor 14 Tahun 1970 tentang Ketentuan-Ketentuan Pokok Kekuasaan Kehakiman dan Pasal 89 KUHAP, tindak pidana koneksitas diperiksa dan diadili oleh pengadilan dalam lingkungan peradilan umum, kecuali jika menurut keputusan Menteri Pertahanan dan Keamanan dengan persetujuan Menteri Kehakiman perkara itu harus diperiksa dan diadili oleh pengadilan dalam lingkungan peradilan militer.

Dalam perkembangannya, sesuai Pasal 22 UU Nomor 35 Tahun 1999 tentang Perubahan Atas UU Nomor 14 Tahun 1970 Tentang Ketentuan-Ketentuan Pokok Kekuasaan Kehakiman, yang diganti dengan Pasal 24 UU Nomor 4 Tahun 2004 tentang Kekuasaan Kehakiman, dan diganti lagi dengan Pasal 16 UU Nomor 48 Tahun 2009 tentang Kekuasaan Kehakiman, tindak pidana koneksitas diperiksa dan diadili oleh pengadilan dalam lingkungan peradilan umum, kecuali 'dalam keadaan tertentu' menurut keputusan Ketua Mahkamah Agung perkara itu harus diperiksa dan diadili oleh pengadilan dalam lingkungan peradilan militer.

Sesuai Penjelasan Pasal 16 UU Nomor 48 Tahun 2009, yang dimaksud dengan "dalam keadaan tertentu" adalah dilihat dari titik berat kerugian yang ditimbulkan oleh tindak pidana tersebut. Jika titik berat kerugian terletak pada kepentingan militer, perkara tersebut diadili oleh pengadilan dalam lingkungan peradilan militer, namun jika titik berat kerugian terletak pada kepentingan umum, maka perkara tersebut diadili oleh pengadilan dalam lingkungan peradilan umum.

Dalam hal perkara tindak pidana koneksitas diadili oleh pengadilan dalam lingkungan peradilan umum, majelis hakim terdiri dari: hakim ketua dari lingkungan peradilan umum, dan hakim anggota ditetapkan secara berimbang masing-masing dari peradilan umum dan peradilan militer. Cara pemeriksaan dan pembuktian di persidangan perkara tindak pidana koneksitas menggunakan acara pemeriksaan biasa. 
c) Acara pemeriksaan singkat.

Ketentuan mengenai acara pemeriksaan singkat diatur dalam Bab XVI, Bagian Kelima, Pasal 203 dan 204 KUHAP. Sesuai ketentuan Pasal 203 KUHAP, yang diperiksa menurut acara pemeriksaan singkat ialah perkara kejahatan atau pelanggaran yang tidak termasuk perkara yang dapat diperiksa menurut acara pemeriksaan tindak pidana ringan, tetapi menurut penuntut umum pembuktian serta penerapan hukumnya mudah dan sifatnya sederhana.

Adapun ciri dan tata cara pemeriksaan perkara kejahatan atau pelanggaran yang dapat diperiksa dan diadili dengan 'acara pemeriksaan singkat' adalah sebagai berikut: ${ }^{74}$

(1) Pembuktian dan penerapan hukumnya mudah, dan sifatnya sederhana. Hal itu dapat dilihat dari kenyataan di berkas perkara bahwa terdakwa pada waktu pemeriksaan penyidikan telah mengakui sepenuhnya atas perbuatan pidana yang didakwakan, yang didukung dengan alat bukti lain yang cukup membuktikan kesalahan terdakwa secara sah menurut undang-undang, sehingga pemeriksaan perkara di persidangan diperkirakan tidak akan memakan waktu yang lama.

(2) Ancaman pidana yang terdapat dalam undang-undang maupun perkiraan hukuman yang akan dijatuhkan oleh hakim tidak berat. Biasanya dalam praktek peradilan umum, hukuman pidana penjara yang dijatuhkan kepada terdakwa dalam acara pemeriksaan singkat tidak lebih dari 3 bulan penjara. Kalau penuntut umum menilai dan berpendapat bahwa pidana yang akan dijatuhkan oleh pengadilan tidak akan lebih dari 3 bulan penjara, penuntut umum dapat mengajukan perkara tersebut untuk diperiksa dengan acara pemeriksaan singkat.

(3) Tata acara pemeriksaan singkat pada umumnya berpedoman pada tata acara pemeriksaan biasa, kecuali beberapa penyederhanaan sebagai berikut:

(a) Perkara dengan acara pemeriksaan singkat dilimpahkan pada hari sidang yang telah ditentukan pengadilan. Pengadilan telah menetapkan hari tertentu dalam setiap minggu untuk memeriksa perkara dengan acara pemeriksaan singkat. Hari tertentu tersebut diberitahukan kepada kejaksaan, sehingga pada setiap hari tertentu tersebut penuntut umum langsung membawa dan melimpahkan perkara singkat di sidang pengadilan tanpa surat pelimpahan perkara dan boleh tanpa surat dakwaan terlebih dahulu.

\footnotetext{
${ }^{74}$ M. Yahya Harahap, Ibid, hal.396-421.
} 
(b) Jika tanpa surat dakwaan, penuntut umum memberitahukan secara lisan kepada terdakwa di sidang pengadilan tentang tindak pidana yang didakwakan.

(c) Biasanya pemeriksaan berlangsung selama satu hari, dan putusan tidak dibuat secara khusus/ tersendiri, melainkan putusan disatukan dan dicatat dalam 'berita acara sidang'.

d) Acara pemeriksaan cepat.

Dalam KUHAP, acara pemeriksaan cepat diatur dalam Bab XVI, Bagian Keenam, Pasal 205 s/d Pasal 216 KUHAP. Pemeriksaan perkara pidana dengan 'acara pemeriksaan cepat' terbagi dalam dua paragraf, yaitu:

(1) Acara pemeriksaan tindak pidana ringan; dan

(2) Acara pemeriksaan perkara pelanggaran lalu lintas jalan.

Sesuai ketentuan Pasal 205 KUHAP, yang diperiksa menurut acara pemeriksaan tindak pidana ringan ialah: perkara yang diancam dengan pidana penjara atau kurungan paling lama tiga bulan dan/atau denda sebanyak-banyaknya tujuh ribu lima ratus rupiah; dan penghinaan ringan.

Dalam menyelesaikan perkara pidana yang diperiksa menurut acara pemeriksaan tindak pidana ringan, dalam waktu tiga hari sejak berita acara pemeriksaan selesai dibuat, penyidik atas kuasa penuntut umum menghadapkan terdakwa beserta barang bukti, dan saksi ke sidang pengadilan. Selanjutnya pengadilan mengadili perkara pidana yang diperiksa menurut acara pemeriksaan tindak pidana ringan dengan 'hakim tunggal' tanpa dihadiri jaksa/penuntut umum. Putusan hakim pada acara pemeriksaan tindak pidana ringan merupakan putusan pada tingkat pertama dan terakhir, dalam arti tidak dapat diajukan upaya hukum, kecuali dalam hal dijatuhkan pidana perampasan kemerdekaan.

Sesuai ketentuan Pasal 207 KUHAP, dalam menyelesaikan perkara dengan acara pemeriksaan tindak pidana ringan, pengadilan harus segera menyidangkan perkara pada hari itu juga saat diterimanya berkas perkara dari penyidik. Oleh karena itu pengadilan telah menetapkan satu hari tertentu dari tujuh hari yang ada sebagai hari yang disediakan untuk mengadili perkara dengan acara pemeriksaan tindak pidana ringan.

Mengenai acara pemeriksaan perkara pelanggaran lalu lintas jalan diatur dalam Pasal 211 s/d Pasal 216 KUHAP. Yang diperiksa menurut acara pemeriksaan perkara pelanggaran lalu lintas jalan adalah perkara pelanggaran tertentu terhadap peraturan 
perundang-undangan tentang lalu lintas jalan. Dalam acara pemeriksaan perkara pelanggaran lalu lintas jalan di pengadilan negeri, persidangan tidak perlu dihadiri oleh jaksa/penuntut umum, melainkan penyidik mencatat dan memberitahukan secara tertulis kepada terdakwa tentang hari, tanggal, jam, dan tempat ia harus menghadap sidang pengadilan, dan selanjutnya catatan bersama berita acara pelanggaran lalu lintas (Balang Lalin) diserahkan kepada pengadilan untuk disidangkan pada hari sidang tertentu yang telah ditetapkan oleh pengadilan negeri. Persidangan dengan acara pemeriksaan perkara pelanggaran lalu lintas jalan tetap dilanjutkan walaupun terdakwa tidak hadir. Putusan hakim terhadap perkara pelanggaran lalu lintas jalan bersifat final dan tidak dapat diajukan upaya hukum, kecuali jika putusan tersebut berupa pidana perampasan kemerdekaan, terdakwa dapat mengajukan banding.

Dalam melaksanakan tugas dan tanggung-jawabnya tersebut, pengadilan diberi wewenang melakukan penahanan atau penahanan lanjutan terhadap terdakwa yang diduga telah melakukan tindak pidana yang diancam dengan pidana penjara lima tahun keatas atau tindak pidana tertentu, yang dikhawatirkan terdakwa akan melarikan diri, merusak atau menghilangkan barang bukti, dan/atau mengulangi tindak pidana. Wewenang untuk melakukan penahanan tersebut diberikan kepada :

a) Hakim Ketua pada pengadilan negeri untuk menahan terdakwa selama 30 hari, yang dapat diperpanjang oleh Ketua Pengadilan Negeri untuk waktu paling lama 60 hari;

b) Hakim Ketua pada pengadilan tinggi (dalam hal terdakwa mengajukan banding) untuk menahan terdakwa selama 30 hari, yang dapat diperpanjang oleh Ketua Pengadilan Tinggi untuk waktu paling lama 60 hari;

c) Hakim Ketua pada Mahkamah Agung RI (dalam hal terdakwa mengajukan kasasi) untuk menahan terdakwa selama 50 hari, yang dapat diperpanjang oleh Ketua Mahkamah Agung RI untuk waktu paling lama 60 hari.

\section{5) Tahap Pelaksanaan Putusan}

Sesuai ketentuan Pasal 270 KUHAP, pelaksanaan putusan pengadilan negeri yang telah memperoleh kekuatan hukum tetap dilakukan oleh Jaksa. Putusan pengadilan negeri yang dijatuhkan kepada terdakwa dapat berupa: pidana mati, pidana penjara atau kurungan, pidana denda, pidana bersyarat, dan/atau membayar ganti kerugian dalam hal pihak yang dirugikan dalam perkara pidana meminta penggabungan gugatan ganti rugi pada perkara pidana yang sedang diperiksa. 
Sesuai ketentuan Pasal 271 KUHAP, pelaksanaan pidana mati dilakukan tidak di muka umum dan dilakukan menurut ketentuan undang-undang. Menurut UU Nomor 2/Pnps/1964 tentang Tata Cara Pelaksanaan Pidana Mati Yang Dijatuhkan Oleh Pengadilan Di Lingkungan Peradilan Umum Dan Militer, pelaksanaan pidana mati bagi terpidana yang diputus oleh pengadilan di lingkungan peradilan umum dilakukan dengan cara ditembak sampai mati oleh regu tembak dari Brigade Mobil Polri di bawah pimpinan seorang perwira atas perintah Jaksa Tinggi / Jaksa yang bertanggung jawab atas pelaksanaan pidana mati. Pelaksanaan pidana mati tidak boleh dilakukan di muka umum, melainkan harus dilaksanakan di suatu tempat yang tidak dilihat oleh umum, dalam daerah hukum pengadilan yang menjatuhkan putusan pada tingkat pertama. ${ }^{75}$

Pelaksanaan 'pidana penjara atau kurungan' bagi Terpidana yang telah dijatuhi hukuman berupa pidana penjara atau kurungan oleh peradilan umum dilaksanakan di Lembaga Pemasyarakatan (Lapas). Sesuai UU Nomor 12 Tahun 1995 tentang Pemasyarakatan, Lapas adalah tempat untuk melaksanakan pembinaan bagi narapidana dan anak didik pemasyarakatan. Narapidana adalah terpidana yang menjalani pidana hilang kemerdekaan di Lapas; sedangkan anak didik pemasyarakatan adalah: ${ }^{76}$

1). Anak Pidana, yaitu anak yang berdasarkan putusan pengadilan menjalani pidana di Lapas Anak paling lama sampai berumur 18 tahun;

2) Anak Negara, yaitu anak yang berdasarkan putusan pengadilan diserahkan pada negara untuk dididik dan ditempatkan di Lapas Anak paling lama sampai berumur 18 tahun; dan

3) Anak Sipil, yaitu anak yang atas permintaan orang tua atau walinya memperoleh penetapan pengadilan untuk dididik di Lapas Anak paling lama sampai berumur 18 tahun.

Sesuai ketentuan Pasal 2 UU Nomor 12 Tahun 1995, sistem pemasyarakatan diselenggarakan dalam rangka membentuk Warga Binaan Pemasyarakatan yang terdiri dari narapidana, anak didik pemasyarakatan, dan klien pemasyarakatan, agar menjadi manusia seutuhnya, menyadari kesalahan, memperbaiki diri, dan tidak mengulangi tindak pidana sehingga dapat diterima kembali oleh lingkungan masyarakat, dapat aktif berperan dalam pembangunan, dan dapat hidup secara wajar sebagai warga yang baik dan bertanggung jawab. Oleh karena itu sistem pemasyarakatan berfungsi menyiapkan Warga

\footnotetext{
${ }^{75}$ Disarikan dari ketentuan Pasal 1 s/d Pasal 16 UU Nomor 2/Pnps/1964 tentang Tata Cara Pelaksanaan Pidana Mati Yang Dijatuhkan Oleh Pengadilan Di Lingkungan Peradilan Umum Dan Militer.

${ }^{76}$ Pasal 1 angka 7 dan 8 UU Nomor 12 Tahun 1995 tentang Pemasyarakatan.
} 
Binaan Pemasyarakatan agar dapat berintegrasi secara sehat dengan masyarakat, sehingga dapat berperan kembali sebagai anggota masyarakat yang bebas dan bertanggung jawab.

Mengenai pelaksanaan 'pidana bersyarat', terpidana yang sedang menjalani pidana bersyarat dinamakan 'klien pemasyarakatan'. Klien Pemasyarakatan adalah seseorang yang berada dalam bimbingan Balai Pemasyarakatan. Balai Pemasyarakatan diselenggarakan oleh Menteri Hukum dan HAM, dan dilaksanakan oleh petugas pemasyarakatan. Setiap klien pemasyarakatan wajib mengikuti secara tertib program bimbingan yang diadakan oleh Balai Pemasyarakatan. ${ }^{77}$

Mengenai pelaksanaan 'pidana denda', sesuai ketentuan Pasal 273 KUHAP, jika pengadilan menjatuhkan putusan yang berupa pidana denda, maka kepada terdakwa diberikan jangka waktu selama satu bulan untuk membayar denda tersebut, kecuali pidana denda dalam putusan acara pemeriksaan cepat yang harus dilunasi seketika pada hari itu juga. Dalam hal terdapat alasan yang kuat, jangka waktu pelaksanaan pidana denda dapat diperpanjang untuk waktu paling lama satu bulan.

Mengenai pelaksanaan hukuman yang berupa kewajiban bagi terpidana untuk membayar ganti rugi kepada pihak yang dirugikan dalam perkara gugatan ganti rugi yang digabungkan dengan perkara pidana yang sedang disidangkan, menurut Pasal 274 KUHAP pelaksanaannya dilakukan menurut tatacara putusan perdata, yaitu dilaksanakan oleh juru sita pengadilan negeri. Sesuai ketentuan Pasal 99 ayat (2) KUHAP, besarnya ganti kerugian yang dapat dituntut oleh pihak yang dirugikan adalah hanya sebesar beaya yang secara nyata telah dikeluarkan oleh pihak yang dirugikan sebagai akibat dari tindak pidana yang dilakukan oleh terpidana.

\section{2. Sub Sistem Peradilan Agama}

Struktur kelembagaan dan kewenangan pengadilan di lingkungan peradilan agama yang merupakan bagian dari sistem peradilan di bawah Mahkamah Agung RI diatur dalam UU Nomor 7 Tahun 1989 tentang Peradilan Agama, yang diubah dengan UU Nomor 3 Tahun 2006 tentang Perubahan Atas UU Nomor 7 Tahun 1989 Tentang Peradilan Agama, yang kemudian diubah lagi dengan UU Nomor 50 Tahun 2009 tentang Perubahan Kedua Atas UU Nomor 7 Tahun 1989 Tentang Peradilan Agama.

Sesuai UU Nomor 7 Tahun 1989 jo UU Nomor 50 Tahun 2009, Peradilan Agama bertugas dan berwenang memeriksa, memutus, dan menyelesaikan perkara antara orang-

\footnotetext{
${ }^{77}$ Disarikan dari isi Pasal 39 s/d 43 UU Nomor 12 Tahun 1995 tentang Pemasyarakatan.
} 
orang yang beragama Islam di bidang: a. Perkawinan; b. Kewarisan, Wasiat, dan Hibah yang dilakukan berdasarkan hukum Islam; serta c. Wakaf, Zakat, Infaq, dan Shadaqah. Kemudian berdasarkan UU Nomor 3 Tahun 2006 tentang Perubahan Atas UU Nomor 7 Tahun 1989 tentang Peradilan Agama, tugas dan kewenangan Peradilan Agama seperti yang telah ditentukan dalam UU Nomor 7 Tahun 1989 tersebut ditambah dengan d. Bidang perekonomian syari'ah.

Untuk melaksanakan tugas dan kewenangannya tersebut, sama dengan peradilan umum, peradilan agama membagi wilayah hukumnya sesuai dengan tingkatan pengadilan, yaitu: ${ }^{78}$

a. Pengadilan Agama, sebagai pengadilan tingkat pertama, berkedudukan di ibukota Kabupaten/Kota, dan daerah hukumnya meliputi wilayah Kabupaten/Kota;

b. Pengadilan Tinggi Agama, sebagai pengadilan tingkat banding berkedudukan di ibukota Provinsi, dan daerah hukumnya meliputi wilayah Provinsi.

Berdasarkan UU Nomor 18 Tahun 2001 tentang Otonomi Khusus bagi Provinsi Daerah Istimewa Aceh sebagai Provinsi Nanggroe Aceh Darussalam, Pasal 15 ayat (2) UU Nomor 4 Tahun 2004 tentang Kekuasaan Kehakiman, dan Pasal 3A UU Nomor 50 Tahun 2009 tentang Perubahan Kedua Atas UU Nomor 7 Tahun 1989 Tentang Peradilan Agama, di Provinsi Nanggroe Aceh Darussalam dibentuk Peradilan Syariah Islam atau Mahkamah Syar'iyah sebagai pengadilan khusus dalam lingkungan peradilan agama sepanjang kewenangannya menyangkut kewenangan peradilan agama, dan merupakan pengadilan khusus dalam lingkungan peradilan umum sepanjang kewenangannya menyangkut kewenangan peradilan umum.

Dalam perkembangannya, Mahkamah Syar'iyah di Provinsi Nanggroe Aceh Darussalam selain berwenang melaksanakan tugas dan kewenangan peradilan agama, ia juga berwenang memeriksa dan mengadili perkara-perkara pidana Islam (jinayah) secara bertahab, yang dimulai dari perkara perjudian (maisir), kesusilaan (khalwat), dan mabukmabukan (khamr).

\subsection{Sub Sistem Peradilan Militer}

\subsubsection{Struktur Kelembagaan dan Kewenangan}

\footnotetext{
${ }^{78}$ Disarikan dari ketentuan Pasal 4 dan Pasal 6 UU Nomor 7 Tahun 1989 sebagaimana yang telah diubah dengan UU Nomor 3 Tahun 2006 dan diubah lagi dengan UU Nomor 50 Tahun 2009.
} 
Struktur kelembagaan dan kewenangan pengadilan dalam lingkungan peradilan militer yang merupakan bagian dari sistem peradilan di bawah Mahkamah Agung RI, saat ini masih diatur dalam UU Nomor 31 Tahun 1997 tentang Peradilan Militer, yang dapat disebut sebagai UU Peradilan Militer. UU Peradilan Militer tersebut hingga saat ini belum disesuaikan dengan UU Nomor 4 Tahun 2004 tentang Kekuasaan Kehakiman, karena Rancangan Perubahan terhadap UU Peradilan Militer yang telah dibahas sejak tahun 2005 hingga sekarang belum disepakati oleh DPR dan Pemerintah. Bahkan ketika UU Peradilan Militer belum dapat disesuaikan dengan UU Nomor 4 Tahun 2004, pada tanggal 29 Oktober 2009 UU Nomor 4 Tahun 2004 telah dicabut dan kemudian diganti dengan UU Nomor 48 Tahun 2009 tentang Kekuasaan Kehakiman yang terbaru. Dengan demikian di masa mendatang perubahan terhadap UU Peradilan Militer tidak lagi disesuaikan dengan UU Nomor 4 Tahun 2004, tetapi disesuaikan dengan UU Nomor 48 Tahun 2009 tentang Kekuasaan Kehakiman.

Selain mengatur tentang susunan dan kekuasaan pengadilan dalam lingkungan Peradilan Militer, UU Peradilan Militer juga mengatur tentang susunan dan kekuasaan Oditurat Militer, Hukum Acara Pidana Militer, dan Hukum Acara Tata Usaha Militer.

Dalam Pasal 5 UU Peradilan Militer disebutkan mengenai kedudukan Peradilan Militer dan Oditurat Militer adalah sebagai berikut:

"(1) Peradilan Militer merupakan pelaksana kekuasaan kehakiman di lingkungan Angkatan Bersenjata untuk menegakkan hukum dan keadilan dengan memperhatikan kepentingan penyelenggaraan pertahanan keamanan negara.

(2) Oditurat merupakan badan pelaksana kekuasaan pemerintahan negara di bidang penuntutan dan penyidikan di lingkungan Angkatan Bersenjata berdasarkan pelimpahan dari Panglima, dengan memperhatikan kepentingan penyelenggaraan pertahanan keamanan negara."

Dalam Pasal 9 UU Peradilan Militer disebutkan bahwa pengadilan dalam lingkungan peradilan militer mempunyai tugas dan wewenang:

"1. Mengadili tindak pidana yang dilakukan oleh seseorang yang pada waktu melakukan tindak pidana adalah:

a. Prajurit;

b. Yang berdasarkan undang-undang dipersamakan dengan prajurit;

c. Anggota suatu golongan atau jawatan atau badan atau yang dipersamakan atau dianggap sebagai prajurit berdasarkan undang-undang;

d. Seseorang yang tidak masuk golongan pada huruf a, huruf b, dan huruf c, tetapi atas keputusan Panglima dengan persetujuan Menteri Kehakiman harus diadili oleh suatu pengadilan dalam lingkungan peradilan militer.

2. Memeriksa, memutus, dan menyelesaikan sengketa Tata Usaha Angkatan Bersenjata. 
3. Menggabungkan perkara gugatan ganti rugi dalam perkara pidana yang bersangkutan atas permintaan dari pihak yang dirugikan sebagai akibat yang ditimbulkan oleh tindak pidana yang menjadi dasar dakwaan, dan sekaligus memutus kedua perkara tersebut dalam satu putusan."

Sesuai UU Peradilan Militer, untuk melaksanakan tugas dan kewenangannya tersebut, pengadilan dalam lingkungan peradilan militer terdiri dari :

1) Pengadilan Militer, merupakan pengadilan tingkat pertama bagi militer yang berpangkat Kapten kebawah yang melakukan tindak pidana. Pengadilan Militer berkedudukan di kota tempat markas Kodam atau markas Korem, dengan wilayah hukum disesuaikan pemusatan pasukan di suatu daerah, berdasarkan pertimbangan kepentingan militer yang ditetapkan oleh Panglima TNI.

Sesuai Keputusan Panglima TNI Nomor: Kep/6/X/2003 tanggal 20 Oktober 2003, pada saat ini terdapat 19 Pengadilan Militer di Indonesia, yaitu: Pengadilan Militer (Dilmil) I-01 Banda Aceh, Dilmil I-02 Medan, Dilmil I-03 Padang, Dilmil I-04 Palembang, Dilmil I-05 Pontianak, Dilmil I-06 Banjarmasin, Dilmil I-07 Balikpapan, Dilmil II-08 Jakarta, Dilmil II-09 Bandung, Dilmil II-10 Semarang, Dilmil II-11 Jogyakarta, Dilmil III-12 Surabaya, Dilmil III-13 Madiun, Dilmil III14 Denpasar, Dilmil III-15 Kupang, Dilmil III-16 Makasar, Dilmil III-17 Manado, Dilmil III-18 Ambon, dan Dilmil III-19 Jayapura. .

2) Pengadilan Militer Tinggi, merupakan pengadilan tingkat pertama bagi militer yang berpangkat Mayor keatas yang melakukan tindak pidana; sebagai pengadilan tingkat pertama untuk memeriksa dan memutus perkara sengketa tata usaha militer; dan sebagai pengadilan tingkat banding bagi perkara pidana yang diputus oleh pengadilan militer di wilayah hukumnya.

Sesuai Keputusan Panglima TNI Nomor: Kep/6/X/2003 tanggal 20 Oktober 2003, pada saat ini ada 3 Pengadilan Militer Tinggi di Indonesia, yaitu: Pengadilan Militer Tinggi I yang berkedudukan di Medan, dengan wilayah hukum meliputi provinsi-provinsi (wilayah Kodam) di Pulau Sumatera dan Kalimantan; Pengadilan Militer Tinggi II yang bekedudukan di Jakarta, dengan wilayah hukum meliputi provinsi-provinsi (wilayah Kodam) Banten, DKI Jakarta, Jawa Barat, Jawa Tengah, dan DI Yogyakarta; dan Pengadilan Militer Tinggi III yang berkedudukan di Surabaya, dengan wilayah hukum meliputi provinsi-provinsi (wilayah Kodam) 
Jawa Timur, Pulau Sulawesi, Bali, Kepulauan Nusa Tenggara, Kepulauan Maluku, dan Papua.

3) Pengadilan Militer Utama, merupakan pengadilan tingkat banding bagi perkara pidana yang diperiksa pada tingkat pertama oleh Pengadilan Militer Tinggi, dan sebagai pengadilan tingkat banding bagi perkara sengketa tata usaha militer.

Di Indonesia hanya ada satu Pengadilan Militer Utama yang berkedudukan di Jakarta, dengan wilayah hukum meliputi seluruh wilayah negara Republik Indonesia.

4) Pengadilan Militer Pertempuran, merupakan pengadilan khusus dalam lingkungan peradilan militer yang bersifat mobil mengikuti gerakan pasukan di daerah pertempuran, berkedudukan dan berdaerah hukum di daerah pertempuran, dengan tugas dan wewenang memeriksa dan memutus pada tingkat pertama dan terakhir perkara pidana yang dilakukan oleh yustisiabel peradilan militer di daerah pertempuran.

Pengadilan Militer Pertempuran merupakan organisasi kerangka yang baru akan dibentuk setelah terjadi keadaan perang, dan dibentuk berdasarkan keputusan panglima TNI.

Dalam konsepsi Integrated Criminal Justice System, peradilan pidana merupakan wujud interaksi penegakan hukum yang melibatkan berbagai komponen aparat penegak hukum sebagai sub sistem, yaitu: Penyidik, Penuntut Umum, Pengadilan, dan Lembaga Pemasyarakatan. Di lingkungan peradilan militer, keempat komponen aparat penegak hukum tersebut adalah Polisi Militer selaku penyidik, Oditur Militer selaku penyidik dan penuntut umum, Pengadilan Militer selaku yang memeriksa dan mengadili perkara pidana yang dilakukan prajurit TNI, dan Lembaga Pemasyarakatan Militer (Lemmasmil) sebagai tempat pelaksanaan pidana penjara bagi prajurit TNI yang tidak dijatuhi pidana tambahan pemecatan dari dinas militer.

Setelah ditetapkannya UU Nomor 4 Tahun 2004 tentang Kekuasaan Kehakiman pada tanggal 15 Januari 2004, yang menentukan bahwa organisasi, administrasi, dan finansial lembaga peradilan berada dibawah pembinaan Mahkamah Agung, maka berdasarkan Keputusan Presiden RI Nomor 56 Tahun 2004 tanggal 9 Juli 2004, organisasi, administrasi, dan finansial pengadilan dalam lingkungan peradilan militer dari yang semula (berdasarakan UU Peradilan Militer) berada di bawah pembinaan Mabes ABRI 
(TNI), terhitung sejak tanggal 30 Juni 2004 dialihkan menjadi di bawah pembinaan Mahkamah Agung RI. ${ }^{79}$

Walaupun telah ditentukan bahwa organisasi, administrasi, dan finansial pengadilan dalam lingkungan peradilan militer berada di bawah pembinaan Mahkamah Agung RI, namun untuk pembinaan personil militer yang berdinas di lingkungan peradilan militer masih dilaksanakan oleh Mabes TNI bekerja sama dengan Mahkamah Agung RI, yaitu meliputi antara lain : ${ }^{80}$

1) Pendidikan pengembangan umum dan pendidikan pengembangan spesialisasi keprajuritan dilaksanakan oleh Mabes TNI berkoordinasi dengan Mahkamah Agung RI.

2) Pendidikan profesi dan pembinaan kemampuan teknis yudisial Hakim dan Panitera pada pengadilan dalam lingkungan peradilan militer dilaksanakan oleh Mahkamah Agung RI.

3) Prajurit yang menduduki jabatan struktural dan/atau jabatan fungsional pada pengadilan dalam lingkungan peradilan militer berstatus sebagai prajurit aktif.

4) Kenaikan pangkat dan pemberhentian dari dinas keprajuritan bagi prajurit yang bertugas pada pengadilan dalam lingkungan peradilan militer diproses dan/atau ditentukan oleh Mabes TNI atas usul Mahkamah Agung RI dan/atau atas pertimbangan Mabes TNI.

5) Dalam hal organisasi TNI memerlukan, Panglima TNI dapat menarik kembali prajurit yang bertugas pada pengadilan dalam lingkungan peradilan militer ke Mabes TNI.

Sesuai kebijakan di atas, walaupun undang-undang telah menetapkan bahwa organisasi, administrasi, dan finansial pengadilan di lingkungan peradilan militer berada di bawah pembinaan Mahkamah Agung RI, namun dalam kenyataannya Mahkamah Agung RI tidak dapat membina sepenuhnya personil militer yang berdinas di lingkungan peradilan militer. Dengan kata lain, pembinaan personil militer yang berdinas di lingkungan peradilan militer, termasuk hakim militer, belum sepenuhnya dapat dilepaskan dari Mabes TNI. Hal itu terjadi karena pembinaan personil militer, terutama yang berkaitan dengan administrasi kepangkatan militer, sangat berbeda dengan pembinaan

\footnotetext{
${ }^{79}$ Pasal 2 Keppres RI Nomor 56 Tahun 2004 tentang Pengalihan Organisasi, Administrasi, Dan Finansial Pengadilan Dalam Lingkungan Peradilan Militer Dari Markas Besar TNI Ke Mahkamah Agung RI.

${ }^{80}$ Disarikan dari Surat Keputusan Bersama Ketua Mahkamah Agung RI dan Panglima TNI Nomor: KMA/065A/SKB/IX/2004 dan Nomor: Skep/420/IX/2004 tanggal 01 September 2004 tentang Kerja Sama Dalam Pembinaan Personil Militer Bagi Prajurit TNI Yang Bertugas Pada Pengadilan Dalam Lingkungan Peradilan Militer.
} 
personil 'sipil', sehingga Mahkamah Agung RI sebagai lembaga sipil masih 'harus' bekerja sama dengan Mabes TNI untuk membina administrasi personil militer yang bertugas di lingkungan peradilan militer. Hal demikian menyebabkan pembinaan administrasi personil hakim di lingkungan peradilan militer dalam kedudukannya sebagai 'prajurit aktif' masih bergantung pada Mabes TNI. Bahkan jika organisasi TNI memerlukan, Panglima TNI setiap saat dapat menarik kembali prajurit yang bertugas di lingkungan peradilan militer ke Mabes TNI, tanpa harus berkoordinasi dengan Mahkamah Agung RI. Keadaan demikian dapat berpengaruh negatif pada kemandirian dan kebebasan hakim di lingkungan peradilan militer dalam memutuskan perkara yang ditangani yang seharusnya 'bebas' dari pengaruh siapapun. Walaupun belum sepenuhnya bisa mandiri seperti yang diharapkan, namun pengalihan pembinaan organisasi, administrasi, dan finansial lembaga peradilan militer ke Mahkamah Agung RI telah membuat lembaga peradilan militer jauh lebih mandiri dibanding sebelumnya.

\subsubsection{Proses Penyelesaian Perkara Pidana di Peradilan Militer}

Pada saat ini hukum acara yang digunakan untuk menyelesaikan perkara pidana di lingkungan peradilan militer adalah UU Nomor 31 Tahun 1997 tentang Peradilan Militer, yang dapat disebut sebagai UU Peradilan Militer. Sesuai Penjelasan Umum UU Peradilan Militer, hukum acara pidana pada peradilan militer yang diatur dalam UU Peradilan Militer disusun berdasarkan pendekatan kesisteman dengan memadukan berbagai konsepsi hukum acara pidana nasional yang tertuang dalam UU Nomor 8 Tahun 1981 (KUHAP) dengan berbagai kekhususan acara yang bersumber dari asas dan ciri-ciri tata kehidupan militer. Berdasarkan pendekatan kesisteman tersebut, sepanjang tidak bertentangan dengan asas dan ciri-ciri tata kehidupan militer, berbagai konsepsi dan rumusan hukum acara pidana yang tertuang dalam KUHAP diakomodasikan ke dalam hukum acara pidana militer, yang muatannya mencakup tahap-tahap penyelesaian perkara pidana di lingkungan peradilan militer yang terdiri dari: tahap penyidikan, tahap penyerahan perkara yang didalamnya tercakup tahap penuntutan, tahap pemeriksaan dalam persidangan, dan tahap pelaksanaan putusan, sebagaimana yang akan diuraikan di bawah.

Dalam UU Peradilan Militer tidak secara khusus diatur tentang 'penyelidikan' sebagai salah satu tahap penyelesaian perkara pidana di lingkungan peradilan militer, karena penyelidikan tindak pidana yang diduga dilakukan oleh prajurit TNI merupakan 
fungsi yang melekat pada komandan kesatuan yang pelaksanaannya dilakukan oleh provos kesatuan selaku penyidik pembantu.

\section{1) Tahap Penyidikan.}

Yang dimaksud dengan "penyidikan" menurut UU Peradilan Militer adalah serangkaian tindakan Penyidik ABRI (TNI) dalam hal dan menurut cara yang diatur dalam UU Peradilan Militer untuk mencari serta mengumpulkan bukti-bukti yang dengan bukti itu membuat terang tentang tindak pidana yang terjadi dan guna menemukan tersangkanya. Dalam Pasal 69 UU Peradilan Militer ditentukan bahwa:

(1) Penyidik adalah: ${ }^{81}$
a. Atasan yang Berhak Menghukum (Ankum);
b. Polisi Militer (Pom); dan
c. Oditur.

(2) Penyidik Pembantu adalah: ${ }^{82}$
a. Provos TNI AD;
b. Provos TNI AL;
c. Provos TNI AU; dan
d. Provos Polri.

Setelah keluarnya Tap MPR RI Nomor VI/MPR/2000 tentang Pemisahan TNI dan

Polri, dan kemudian dengan ditundukkannya anggota Polri pada yurisdiksi peradilan umum, Provos Polri tidak lagi sebagai 'penyidik pembantu' di lingkungan peradilan militer.

Sesuai Pasal 71 UU Peradilan Militer, dalam melakukan penyidikan terhadap suatu tindak pidana, penyidik mempunyai wewenang:

"a) Menerima laporan atau pengaduan dari seseorang tentang terjadinya suatu peristiwa yang diduga tindak pidana;

\footnotetext{
81 "Atasan yang berhak menghukum (Ankum)" adalah atasan langsung yang mempunyai wewenang untuk menjatuhkan hukuman disiplin kepada setiap prajurit TNI yang berada di bawah wewenang komandonya menurut ketentuan peraturan perundang-undangan yang berlaku dan berwenang melakukan penyidikan berdasarkan UU Peradilan Militer. Sesuai Keputusan Panglima TNI Nomor: Kep/23/VIII/2005, Ankum yang diberi kewenangan penuh, termasuk untuk menahan anggotanya dalam rangka penyidikan, adalah para Komandan Kesatuan setingkat Batalyon (Dan Yon) ke atas. "Penyidik Polisi Militer (Pom)" adalah salah seorang pejabat yang mendapat pelimpahan wewenang dari panglima TNI selaku Ankum tertinggi untuk melakukan penyidikan terhadap tindak pidana yang dilakukan oleh prajurit. "Oditur" yang terdiri dari Oditur Militer dan Oditur Militer Tinggi adalah pejabat yang diberi wewenang untuk bertindak sebagai penuntut umum, sebagai pelaksana putusan atau penetapan pengadilan dalam lingkungan peradilan militer atau pengadilan dalam lingkungan peradilan umum dalam perkara pidana, dan sebagai penyidik sesuai ketentuan UU Peradilan Militer.

82 "Provos" adalah bagian organik satuan yang tugasnya membantu Komando/Pimpinan pada markas/kapal/ksatrian/pangkalan dalam menyelenggarakan penegakan hukum, disiplin, tata tertib, dan pengamanan lingkungan kesatuannya. Provos sebagai penyidik pembantu mempunyai kewenangan yang sama dengan penyidik sebagaimana yang ditentukan dalam Pasal 71 dan Pasal 72 UU Peradilan Militer terhadap tindak pidana yang terjadi di kesatuannya, kecuali dalam hal pemberkasan dan penyerahan berkas perkara kepada Oditurat Militer.
} 
b) Melakukan tindakan pertama pada saat dan di tempat kejadian;

c) Mencari keterangan dan barang bukti;

d) Menyuruh berhenti seseorang yang diduga sebagai tersangka dan memeriksa tanda pengenalnya;

e) Melakukan penangkapan, penggeledahan, penyitaan, dan pemeriksaan suratsurat;

f) Mengambil sidik jari dan memotret seseorang;

g) Memanggil seseorang untuk didengar dan diperiksa sebagai tersangka atau saksi;

h) Meminta bantuan pemeriksaan seorang ahli atau mendatangkan orang ahli yang diperlukan dalam hubungannya dengan pemeriksaan perkara; dan

i) Mengadakan tindakan lain menurut hukum yang bertanggung jawab."

Walaupun penyidik di lingkungan peradilan militer ada tiga pejabat/lembaga, yaitu: Ankum, Pom, dan Oditur, namun sesuai Pasal 74 UU Peradilan Militer, kewenangan Ankum sebagai penyidik adalah terbatas, yaitu:

"a) Ankum hanya melakukan penyidikan terhadap prajurit bawahannya yang ada di bawah wewenang komandonya, yang pelaksanaannya dilakukan oleh penyidik Pom atau penyidik Oditur;

b) Ankum menerima laporan pelaksanaan penyidikan dari penyidik Pom atau penyidik Oditur;

c) Ankum menerima berkas perkara hasil penyidikan dari penyidik Pom atau penyidik Oditur; dan

d) Ankum berwenang melakukan penahanan sementara paling lama 20 hari terhadap tersangka yang ada di bawah wewenang komandonya."

Sesuai penjelasan Pasal 74 UU Peradilan Militer, terbatasnya kewenangan Ankum selaku penyidik dimaksudkan agar pelaksanaan kewenangan penyidikan yang ada pada Ankum dapat lebih efektif dan Ankum dapat lebih memusatkan perhatian pada pelaksanaan tugas pokoknya. Oleh karena itu pelaksanaan penyidikan terhadap prajurit bawahan Ankum dilakukan oleh penyidik Pom atau Oditur, dan Ankum cukup menerima laporan pelaksanaan penyidikan dari penyidik Pom atau Oditur. Sebaliknya, sebagai penanggung jawab keadaan satuan dan anggotanya, hanya Ankum yang berwenang mengeluarkan surat penahanan sementara bagi prajurit di bawah wewenang komandonya yang sedang menjalani proses penyidikan.

Dalam penyelesaian perkara di peradilan militer, Ankum diberi wewenang sebagai penyidik, karena sesuai 'asas kesatuan komando', ${ }^{83}$ Komandan bertanggung jawab penuh

83 Yang dimaksud 'asas kesatuan komando' dalam kehidupan militer ialah bahwa dalam kehidupan militer dengan struktur organisasinya, hanya ada satu komando/pimpinan, yaitu Panglima TNI, yang kemudian Panglima TNI sebagai pemegang komando secara berjenjang dapat mendelegasikan komandonya kepada para komandan kesatuan dibawahnya. Oleh karena itu seorang komandan kesatuan mempunyai kedudukan yang sentral dan bertanggung jawab penuh kepada Komandan diatasnya atas segala hal yang 
terhadap kesatuan dan anak buahnya. Oleh karena itu wewenang penyelidikan dan penyidikan tindak pidana yang dilakukan oleh prajurit yang berada di bawah wewenang komandonya merupakan wewenang yang melekat pada Ankum, yang maksudnya agar Ankum dapat ikut menentukan nasib anggotanya tersebut dalam penyelesaian perkara pidana. Namun demikian wewenang penyidikan yang ada pada Ankum tersebut tidak dilaksanakan sendiri oleh Ankum, melainkan dilaksanakan oleh penyidik Pom dan/atau Oditur. Pelaksanaan wewenang penyidikan Ankum oleh Pom dan/atau Oditur tersebut adalah dalam hal pembuatan berkas perkara dan pelimpahannya kepada Oditurat Militer untuk dilakukan tindakan penuntutan. ${ }^{84}$

Sesuai Pasal 72 UU Peradilan Militer, atas tindakan penyidikan yang dilakukan, penyidik membuat berita acara tentang pelaksanaan tindakan penyidikan, kemudian penyidik membuat berkas perkara hasil penyidikan, dan selanjutnya berkas perkara tersebut diserahkan kepada Papera, Ankum, dan Oditur selaku penuntut umum. Untuk penyerahan berkas perkara kepada Oditur penuntut umum disertai dengan penyerahan tanggung jawab atas tersangka dan barang bukti.

Mengenai kewenangan menahan, berbeda dengan sistem yang berlaku di lingkungan peradilan umum, di mana penyidik maupun penuntut umum masing-masing mempunyai kewenangan untuk menahan tersangka/terdakwa yang sedang menjalani proses penyidikan dan/atau penuntutan, maka Penyidik Pom dan Oditur di lingkungan peradilan militer tidak mempunyai kewenangan untuk menahan tersangka prajurit TNI.

Sesuai Pasal 78 UU Peradilan Militer, yang berwenang melakukan penahanan terhadap tersangka prajurit TNI yang sedang menjalani proses penyidikan adalah Ankum yang bersangkutan untuk waktu paling lama 20 hari. Dalam hal masih diperlukan penahanan guna kepentingan pemeriksaan yang belum selesai, masa penahanannya dapat diperpanjang oleh Papera ${ }^{85}$ yang berwenang untuk setiap kali perpanjangan selama 30

terjadi pada kesatuan dan anak buahnya. Sebagai bentuk tanggung jawab komandonya, seorang komandan diberi wewenang penyelidikan, penyidikan, dan wewenang penyerahan perkara dalam penyelesaian perkara pidana yang diduga dilakukan oleh anak buahnya, serta berkewajiban untuk menyelesaikan sengketa tata usaha militer yang diajukan oleh anak buahnya melalui upaya administrasi.

${ }^{84}$ Disarikan dari ketentuan Pasal 73 dan Penjelasan Pasal 69 UU Peradilan Militer

${ }^{85}$ Perwira Penyerah Perkara (Papera) adalah perwira yang oleh atau atas dasar undang-undang diberi wewenang untuk menentukan suatu perkara pidana yang dilakukan oleh prajurit TNI yang berada di bawah wewenang komandonya diserahkan kepada atau diselesaikan di luar pengadilan dalam lingkungan peradilan militer atau pengadilan dalam lingkungan peradilan umum. Sesuai Pasal 122 UU Peradilan Militer, yang berwenang sebagai Papera adalah Panglima TNI sebagai Papera tertinggi di lingkungan TNI, dan Kasad, Kasal, serta Kasau sebagai Papera di lingkungan angkatan masing-masing. Para Papera tersebut dapat menunjuk para Komandan/Kepala kesatuan dibawahnya paling rendah setingkat dengan Komandan Korem/Lanal/Lanud/Brigade, untuk bertindak selaku Papera. 
hari, dan paling lama 180 hari. Sesudah waktu 200 (dua ratus) hari kewenangan menahan oleh Ankum dan Papera habis, tersangka yang masih dalam penahanan sementara harus dikeluarkan dari tahanan demi hukum. Sesuai Penjelasan Umum UU Peradilan Militer, penahanan oleh Ankum dan Papera hanya dapat dilaksanakan di rumah tahanan militer, karena di lingkungan peradilan militer hanya dikenal satu jenis penahanan, yaitu penahanan di rumah tahanan militer. Dengan kata lain, di lingkungan peradilan militer tidak dikenal istilah penahanan rumah maupun penahanan kota.

Sesuai Pasal 79 UU Peradilan Militer, penahanan atau perpanjangan penahanan dapat dilakukan terhadap tersangka atau terdakwa prajurit TNI yang diduga telah melakukan tindak pidana yang diancam pidana penjara 3 (tiga) bulan atau lebih, dikhawatirkan akan melarikan diri, merusak atau menghilangkan barang bukti, atau mengulangi tindak pidana, atau membuat keonaran.

\section{2) Tahap Penyerahan Perkara}

Yang dimaksud "Penyerahan Perkara" adalah tindakan Papera untuk menyerahkan perkara pidana ke pengadilan dengan menuntut supaya diperiksa dan diadili dalam hal dan menurut cara yang diatur dalam undang-undang. Penyerahan perkara tersebut dilakukan berdasarkan keputusan Papera dan dilaksanakan oleh Oditur dengan melimpahkan perkara ke pengadilan militer yang berwenang.

Sesuai Penjelasan Umum UU Peradilan Militer, wewenang penyerahan perkara pidana yang dilakukan oleh prajurit TNI kepada pengadilan dalam lingkungan peradilan militer maupun pengadilan dalam lingkungan peradilan umum (dalam perkara koneksitas) ada pada Papera. Dalam hukum acara pidana militer, tahap penuntutan termasuk dalam tahap penyerahan perkara, dan pelaksanaan penuntutan dilakukan oleh Oditur selaku penuntut umum yang secara teknis yuridis bertanggung jawab kepada Oditur Jenderal (Orjen) TNI, dan secara operasional justisial bertanggung jawab kepada Papera.

Setelah Oditur selaku penuntut umum menerima berkas perkara hasil penyidikan dari penyidik Pom atau penyidik Oditur, maka Oditur Penuntut Umum lalu meneliti dan mengolah berkas perkara untuk diselesaikan sesuai ketentuan undang-undang yang berlaku, dengan melakukan kegiatan sebagai berikut $:{ }^{86}$

a) Oditur segera mempelajari dan meneliti apakah hasil penyidikan sudah lengkap atau belum.

\footnotetext{
${ }^{86}$ Disarikan dari ketentuan Pasal 124 s/d Pasal 131 UU Peradilan Militer.
} 
b) Dalam hal hasil penyidikan ternyata belum lengkap, Oditur dapat melengkapi sendiri dengan melakukan pemeriksaan tambahan, atau Oditur mengembalikan berkas perkara kepada penyidik Pom disertai petunjuk tentang hal-hal yang harus dilengkapi.

c) Setelah berkas perkara lengkap dan memenuhi syarat, Oditur lalu membuat dan menyampaikan pendapat hukum kepada Papera, yang isinya dapat berupa permintaan agar perkara diserahkan kepada pengadilan, atau perkara diselesaikan menurut hukum disiplin, atau perkara ditutup demi kepentingan hukum/demi kepentingan umum/demi kepentingan militer. ${ }^{8721}$

d) Berdasarkan pendapat hukum dari Oditur tersebut, Papera lalu mengeluarkan Surat Keputusan Penyerahan Perkara (Skeppera), atau Surat Keputusan Penyelesaian Perkara Menurut Hukum Disiplin (Skepkumplin), atau Surat Keputusan Penutupan Perkara Demi Kepentingan Hukum (Skeptupra).

e) Dalam hal terjadi perbedaan pendapat antara Oditur dan Papera tentang penyelesaian perkara prajurit yang berada di bawah wewenang komandonya, yaitu Papera menghendaki agar perkara diselesaikan di luar pengadilan sedangkan Oditur berpendapat bahwa perkara harus diajukan ke pengadilan, maka perbedaan pendapat tersebut diputuskan oleh Pengadilan Militer Utama (Dilmiltama) dalam sidang yang memeriksa permohonan dan alasan Oditur, pendapat tertulis Papera, dan pendapat Orjen TNI.

f) Setelah mendengar pendapat Orjen TNI, Hakim Dilmiltama memutuskan tentang apakah perkara tersebut diajukan atau tidak diajukan ke pengadilan. Dalam hal Dilmiltama memutuskan perkara tersebut harus diajukan ke pengadilan, maka Papera wajib segera melaksanakan penyerahan perkara tersebut ke pengadilan melalui oditurat, dengan mengeluarkan Skeppera;

g) Berdasarkan Skeppera dari Papera, Oditur melimpahkan berkas perkara kepada pengadilan yang berwenang dengan disertai surat dakwaan. Salinan skeppera dan surat dakwaan disampaikan kepada Tersangka pada saat bersamaan dengan pelimpahan perkara ke pengadilan, dan tembusannya disampaikan kepada penyidik.

\section{3) Tahap Pemeriksaan Di Persidangan Pengadilan}

21 Sesuai Pasal 126 ayat (2) UU Peradilan Militer, kewenangan mengeluarkan Surat Keputusan Penutupan Perkara demi kepentingan umum atau kepentingan militer hanya ada pada Panglima TNI setelah mendengar pendapat dari Orjen TNI dan jika dipandang perlu juga pendapat dari pejabat lain. 
Tata cara pemeriksaan, pembuktian, upaya hukum, dan kewenangan pengadilan untuk menahan terdakwa dalam proses penyelesaian perkara pidana di pengadilan dalam lingkungan peradilan militer pada dasarnya sama dengan proses penyelesaian peraka pidana di pengadilan dalam lingkungan peradilan umum. Adapun hal yang berbeda dalam proses penyelesaian perkara pidana di pengadilan dalam lingkungan peradilan militer jika dibandingkan dengan proses penyelesaian perkara pidana di pengadilan dalam lingkungan peradilan umum adalah sebagai berikut $::^{88}$

a) Jika jenis acara pemeriksaan perkara pidana di pengadilan negeri terdiri dari: Acara Pemeriksaan Biasa, Acara Pemeriksaan Koneksitas, Acara Pemeriksaan Singkat, dan Acara Pemeriksaan Cepat; maka jenis acara pemeriksaan perkara pidana di pengadilan dalam lingkungan peradilan militer terdiri dari: Acara Pemeriksaan Biasa, Acara Pemeriksaan Koneksitas, Acara Pemeriksaan Cepat, dan Acara Pemeriksaan Khusus. Acara pemeriksaan biasa di pengadilan dalam lingkungan peradilan militer sama dengan acara pemeriksaan biasa di pengadilan negeri.

b) Dalam hal tindak pidana koneksitas diadili di pengadilan dalam lingkungan peradilan militer, maka majelis hakim terdiri dari: hakim ketua dari lingkungan peradilan militer, dan hakim anggota ditetapkan secara berimbang masing-masing hakim dari lingkungan peradilan militer dan hakim dari lingkungan peradilan umum yang diberi pangkat 'militer tituler'. ${ }^{89}$ Adapun tatacara pemeriksaan dan pembuktian dalam acara pemeriksaan koneksitas di pengadilan dalam lingkungan peradilan militer pada dasarnya sama dengan yang berlaku di lingkungan peradilan umum.

c) Jika acara pemeriksaan cepat di pengadilan negeri digunakan untuk memeriksa perkara tindak pidana ringan yang diancam dengan pidana penjara paling lama tiga bulan, penghinaan ringan, dan perkara pelanggaran lalu lintas jalan; maka acara pemeriksaan cepat di peradilan militer hanya digunakan untuk memeriksa perkara pelanggaran lalu lintas jalan saja. Sedangkan perkara tindak pidana ringan yang

\footnotetext{
${ }^{88}$ Disarikan dari ketentuan Pasal 132 s/d Pasal 253 UU Peradilan Militer.

${ }^{89}$ Sesuai PP Nomor 36 Tahun 1959 jo PP Nomor 13 Tahun 1983, yang dimaksud pangkat "militer tituler" adalah pangkat yang diberikan oleh Menteri Pertahanan kepada komponen sipil atau tenaga non militer yang karena kepentingan tugas dan jabatannya 'dalam keadaan darurat untuk kepentingan pertahanan negara' memerlukan pangkat militer. PNS yang diangkat menjadi militer dengan pangkat tituler tetap berstatus sebagai PNS, sehingga kepangkatan militernya pun mengikuti administrasi kepangkatan PNS, karena pemberian pangkat tituler bersifat sementara sesuai dengan kebutuhan Dephan/TNI. Namun dengan diangkatnya PNS menjadi anggota militer tituler membawa akibat pada bertambahnya beban tugas dan kewajiban PNS yang bersangkutan serupa dengan anggota militer pada umumnya. Oleh karena itu sebagai imbangannya kepada anggota militer tituler diberikan hak perawatan personil dan tunjangan-tunjangan lain yang diperoleh anggota militer pada umumnya.
} 
diancam dengan pidana penjara paling lama tiga bulan, dapat diselesaikan oleh Ankum melalui prosedur penyelesaian perkara pelanggaran hukum disiplin militer; dan perkara tindak pidana yang diancam dengan pidana penjara di atas tiga bulan, harus diselesaikan melalui acara pemeriksaan biasa di pengadilan.

d) Pada prinsipnya pengadilan dalam lingkungan peradilan militer bersidang dengan Hakim Majelis, kecuali dalam acara pemeriksaan cepat pengadilan militer bersidang dengan Hakim Tunggal.

e) Kehadiran Terdakwa di persidangan pengadilan militer pada dasarnya adalah melaksanakan 'perintah dinas' dari Ankum/Papera. Oleh karena itu pemanggilan Terdakwa ke persidangan pengadilan militer harus melalui Komandan kesatuan selaku Ankum terdakwa.

f) Untuk kepentingan pembelaan perkaranya, pada prinsipnya tersangka/ terdakwa berhak untuk didampingi penasehat hukum di semua tingkat pemeriksaan, baik dari militer maupun dari sipil. Jika penasehat hukum dari militer harus atas perintah Papera, dan jika penasehat hukum dari sipil harus atas izin Papera. Dalam hal terdakwa wajib didampingi oleh penasehat hukum, karena terdakwa diduga melakukan tindak pidana yang diancam dengan pidana penjara 15 (lima belas) tahun atau lebih, maka Papera wajib menunjuk penasehat hukum bagi tersangka/terdakwa.

g) Acara pemeriksaan khusus dilaksanakan oleh Pengadilan Militer Pertempuran untuk memeriksa dan memutus perkara pidana pada tingkat pertama dan terakhir, yang dilakukan oleh prajurit TNI di daerah pertempuran. Terhadap putusan dalam acara pemeriksaan khusus tersebut, terdakwa atau oditur hanya dapat mengajukan kasasi ke Mahkamah Agung RI.

\section{4) Tahap Pelaksanaan Putusan Pengadilan}

Sesuai Pasal 254 UU Peradilan Militer, putusan pengadilan yang telah memperoleh kekuatan hukum tetap, pelaksanaannya dilakukan oleh Oditur. Putusan pengadilan dalam lingkungan peradilan militer yang dijatuhkan kepada terdakwa dapat berupa pidana pokok dan pidana tambahan, atau hanya pidana pokok saja. Pidana pokok berupa: pidana mati; pidana penjara; pidana kurungan; pidana denda. Pidana tambahan berupa: pemecatan dari dinas militer; penurunan pangkat; pencabutan hak-hak yang disebutkan pada Pasal 35 ayat (1) ke-1, ke-2, dan ke-3 KUHP. 
Sesuai Pasal 26 jo Pasal 6 KUHPM, Terdakwa prajurit TNI yang dijatuhi pidana mati atau pidana penjara, kepadanya dapat dijatuhkan 'pidana tambahan' yang berupa pemecatan dari dinas militer. Pemecatan dari dinas militer tersebut didasarkan pada pertimbangan bahwa dengan kejahatannya tersebut, terdakwa dipandang tidak layak lagi tetap berada dalam kalangan militer.

Menurut S.R. Sianturi, ${ }^{90}$ ukuran penjatuhan pidana tambahan 'pemecatan dari dinas militer' di samping beratnya pidana pokok ialah 'pandangan hakim militer' mengenai kejahatan yang dilakukan oleh terdakwa berdasarkan 'nilai' sebagai tidak layak lagi dipertahankan dalam kehidupan masyarakat militer. Apabila kepada terdakwa dijatuhkan pidana tambahan pemecatan dari dinas militer, maka dalam pandangan hakim militer itu harus tercakup atau tersirat suatu makna bahwa apabila tidak dijatuhkan pidana tambahan pemecatan dari dinas militer, kehadiran kembali terpidana dalam masyarakat militer -setelah ia selesai menjalani pidananya- akan menggoncangkan sendi-sendi ketertiban dalam masyarakat militer. Oleh karena itu hanya 'hakim militer' yang berwenang menjatuhkan pidana tambahan 'pemecatan dari dinas militer'. Dengan kata lain, hakim peradilan umum tidak berwenang menjatuhkan pidana tambahan 'pemecatan dari dinas militer' terhadap terdakwa prajurit TNI. Karena pidana tambahan pemecatan dari dinas militer bersifat khas militer, sehingga hakim militer dipandang lebih mengetahui seluk beluk dan tata kehidupan militer, yang dengan pengetahuannya tersebut hakim militer lebih mendalami hal-hal yang layak atau tidak layak bagi kehidupan militer.

Mengenai pelaksanaan 'pidana mati' bagi prajurit TNI yang dijatuhi pidana mati, sesuai ketentuan Pasal 255 UU Peradilan Militer jo UU Nomor 2 / Pnps / 1964 tentang Tata Cara Pelaksanaan Pidana Mati Yang Dijatuhkan Oleh Pengadilan Di Lingkungan Peradilan Umum dan Militer, pelaksanaannya dilakukan dengan cara ditembak sampai mati oleh regu tembak dari Polisi Militer di bawah pimpinan seorang perwira atas perintah Oditur yang bertanggung jawab atas pelaksanaan pidana mati. Pelaksanaan pidana mati tidak boleh dilakukan di muka umum, melainkan dilaksanakan di suatu tempat yang tidak dilihat oleh umum, dalam daerah hukum pengadilan yang menjatuhkan putusan pada tingkat pertama. ${ }^{91}$

\footnotetext{
${ }^{90}$ S.R. Sianturi, Hukum Pidana Militer di Indonesia, Alumni Ahaem-Petehaem, Jakarta, Cetakan Kedua: 1985, hal.96-99

${ }^{91}$ Disarikan dari ketentuan Pasal 1 s/d Pasal 17 UU Nomor 2/Pnps/1964 tentang Tata Cara Pelaksanaan Pidana Mati Yang Dijatuhkan Oleh Pengadilan Di Lingkungan Peradilan Umum Dan Militer.
} 
Sesuai Pasal 256 UU Peradilan Militer, pelaksanaan 'pidana penjara' atau 'pidana kurungan' bagi terpidana yang telah dijatuhi hukuman berupa pidana penjara atau kurungan oleh pengadilan dalam lingkungan peradilan militer dilaksanakan di:

a) Lembaga Pemasyarakatan Militer (Lemmasmil) atau di tempat lain menurut ketentuan undang-undang;

b) Dalam hal terpidana juga dijatuhi pidana tambahan pemecatan dari dinas militer, maka pidana penjaranya dilaksanakan di Lembaga Pemasyarakatan Umum (Lapas).

Pelaksanaan pidana penjara bagi terpidana militer, selama ia belum dipecat dari dinas militer, adalah merupakan pendidikan atau pembinaan agar setelah selesai menjalani pidananya nanti Ia dapat kembali menjadi militer yang baik dalam kesatuannya. Oleh karena itu tujuan pemidanaan di peradilan militer dan juga tujuan pembinaan narapidana di Lemmasmil, selain untuk menjadikan prajurit yang terlanjur bersalah agar dapat kembali menjadi manusia seutuhnya, menyadari kesalahan, memperbaiki diri, dan tidak mengulangi lagi tindak pidana, sehingga setelah keluarnya ia dari Lemmasmil dapat diterima kembali oleh lingkungan masyarakatnya. ${ }^{92}$ Sedang tujuan yang lebih penting adalah agar terpidana tersebut setelah keluar dari Lemmasmil dapat kembali menjadi prajurit yang baik dan bertanggung-jawab sesuai falsafah Pancasila dan Sapta Marga. ${ }^{93}$

Sehubungan dengan tujuan pembinaan narapidana militer di Lemmasmil, sesuai Keputusan Panglima TNI Nomor: Kep/24/VIII/2005 tanggal 10 Agustus 2005 tentang Organisasi dan Prosedur Badan Pembinaan Hukum TNI, pada pokoknya tugas pokok Lemmasmil adalah :

a) Melaksanakan pembinaan mental Sapta Marga terhadap narapidana TNI;

b) Melaksanakan pendidikan dan latihan terhadap narapidana TNI sebagai rehabilitasi;

c) Melaksanakan pembinaan jasmani militer bagi narapidana TNI;

d) Melaksanakan pengamanan, tata tertib, dan disiplin di lingkungan pemasyarakatan militer

\footnotetext{
92 Tujuan pembinaan narapidana di lembaga pemasyarakatan umum menurut Pasal 2 UU Nomor 12 Tahun 1995 tentang Pemasyarakatan.

${ }^{93}$ Falsafah Sapta Marga adalah falsafah hidup yang menjadi landasan kejuangan dan tekad setiap prajurit TNI dalam melaksanakan tugasnya. Sapta Marga terdiri dari tujuh butir tekad prajurit, yaitu: 1. Kami warga negara kesatuan Republik Indonesia yang bersendikan Pancasila; 2. Kami patriot Indonesia, pendukung serta pembela ideologi negara yang bertanggung-jawab dan tidak mengenal menyerah; 3. Kami ksatria Indonesia, yang bertaqwa kepada Tuhan Yang Maha Esa, serta membela kejujuran, kebenaran, dan keadilan; 4. Kami prajurit Tentara Nasional Indonesia, adalah bhayangkari negara dan bangsa Indonesia; 5. Kami prajurit Tentara Nasional Indonesia, memegang teguh disiplin, patuh dan taat kepada pimpinan serta menjunjung tinggi sikap dan kehormatan prajurit; 6. Kami prajurit Tentara Nasional Indonesia, mengutamakan keperwiraan di dalam melaksanakan tugas, serta senantiasa siap sedia berbakti kepada negara dan bangsa; 7. Kami prajurit Tentara Nasional Indonesia, setia dan menepati janji serta sumpah prajurit.
} 
Mengenai pelaksanaan 'pidana denda', sesuai Pasal 258 UU peradilan Militer, jika pengadilan menjatuhkan pidana denda, kepada terpidana diberikan jangka waktu selama satu bulan untuk membayar dendanya, sedangkan pidana denda dalam putusan acara pemeriksaan cepat dilunasi seketika pada hari itu juga. Dalam hal terdapat alasan yang kuat, jangka waktu pelaksanaan pidana denda dapat diperpanjang untuk waktu paling lama satu bulan.

Mengenai pelaksanaan 'pidana bersyarat' bagi terpidana prajurit TNI yang dijatuhi pidana bersyarat, Oditur menyerahkan Terpidana prajurit TNI kepada Ankumnya untuk dilakukan pengawasan dan pembinaan agar terpidana tidak melanggar syarat umum maupun syarat khusus yang telah ditentukan. Sesuai ketentuan Pasal 16 KUHPM, yang menjadi syarat umum dalam penjatuhan pidana bersyarat adalah selain terpidana tidak boleh melakukan tindak pidana lagi selama dalam masa percobaan sebagaimana yang ditentukan dalam Pasal 14a KUHP, terpidana juga tidak boleh melakukan pelanggaran disiplin militer yang bersifat berat, dalam arti dijatuhi hukuman disiplin penahanan berat oleh Ankum selama dalam masa percobaan.

Sesuai ketentuan Pasal 186 UU Peradilan Militer, hukuman yang berupa kewajiban bagi terpidana untuk membayar ganti rugi kepada pihak yang dirugikan dalam perkara gugatan ganti rugi yang digabungkan dengan perkara pidana yang sedang disidangkan, pelaksanaannya dilakukan oleh Kepala Kepaniteraan (Panitera) Pengadilan Militer yang karena jabatannya adalah 'juru sita', khusus untuk pelaksanaan putusan ganti rugi akibat penggabungan gugatan ganti rugi kepada perkara pidana. Sesuai ketentuan Pasal 184 ayat (2) UU Peradilan Militer, besarnya ganti kerugian yang dapat dikabulkan oleh hakim adalah hanya sebesar beaya yang secara nyata telah dikeluarkan oleh pihak yang dirugikan sebagai akibat dari tindak pidana yang dilakukan terpidana.

\subsection{Sub Sistem Peradilan Tata Usaha Negara.}

Struktur kelembagaan dan kewenangan pengadilan dalam lingkungan peradilan tata usaha negara yang merupakan bagian dari sistem peradilan di bawah Mahkamah Agung RI diatur dalam UU Nomor 5 Tahun 1986 tentang Peradilan Tata Usaha Negara, yang diubah dengan UU Nomor 9 Tahun 2004 tentang Perubahan Atas UU Nomor 5 Tahun 1986 Tentang Peradilan Tata Usaha Negara, dan kemudian diubah lagi dengan UU Nomor 51 Tahun 2009 tentang Perubahan Kedua Atas UU Nomor 5 Tahun 1986 Tentang Peradilan Tata Usaha Negara. 
Sesuai Pasal 6 UU Nomor 9 Tahun 2004 jo Pasal 1 UU Nomor 51 Tahun 2009, Peradilan Tata Usaha Negara adalah salah satu pelaku kekuasaan kehakiman bagi rakyat pencari keadilan terhadap 'sengketa tata usaha negara'. Yang dimaksud dengan "sengketa tata usaha negara" adalah sengketa yang timbul dalam bidang tata usaha negara antara orang atau badan hukum perdata dengan badan atau pejabat tata usaha negara, baik di pusat maupun di daerah, sebagai akibat dikeluarkannya 'keputusan tata usaha negara', termasuk sengketa kepegawaian berdasarkan peraturan perundang-undangan yang berlaku. Selanjutnya yang dimaksud dengan "keputusan tata usaha negara" adalah suatu penetapan tertulis yang dikeluarkan oleh Badan atau Pejabat tata usaha negara yang berisi tindakan hukum tata usaha negara berdasarkan peraturan perundang-undangan yang berlaku, yang bersifat konkret, individual, dan final, yang menimbulkan akibat hukum bagi seseorang atau badan hukum perdata.

Sesuai Pasal 2 UU Nomor 9 Tahun 2004, tidak termasuk dalam pengertian 'keputusan tata usaha negara', yakni:

"a. Keputusan tata usaha negara yang merupakan perbuatan hukum perdata;

b. Keputusan tata usaha negara yang merupakan pengaturan yang besifat umum;

c. Keputusan tata usaha negara yang masih memerlukan persetujuan;

d. Keputusan tata usaha negara yang dikeluarkan berdasarkan ketentuan KUHP dan KUHAP atau peraturan perundang-undangan lain yang bersifat hukum pidana;

e. Keputusan tata usaha negara yang dikeluarkan atas dasar hasil pemeriksaan badan peradilan berdasarkan ketentuan peraturan perundang-undangan yang belaku;

f. Keputusan tata usaha negara mengenai tata usaha TNI;

g. Keputusan Komisi Pemilihan Umum baik di pusat maupun di daerah mengenai hasil pemilihan umum."

Untuk melaksanakan tugas dan wewenangnya tersebut, peradilan tata usaha negara membagi wilayah hukum sesuai tingkatan pengadilannya, yaitu: ${ }^{94}$

a. Pengadilan Tata Usaha Negara (PTUN), sebagai pengadilan tingkat pertama, berkedudukan di ibukota Kabupaten/Kota, dengan wilayah hukum meliputi wilayah Kabupaten/Kota.

b. Pengadilan Tinggi Tata Usaha Negara (PTTUN), sebagai pengadilan tingkat banding berkedudukan di ibukota Provinsi, dengan wilayah hukum meliputi wilayah Provinsi.

\footnotetext{
${ }^{94}$ Disarikan dari ketentuan Pasal 6 dan Pasal 8 UU Nomor 5 Tahun 1986 sebagaimana yang telah diubah dengan UU Nomor 9 Tahun 2004 dan diubah lagi dengan UU Nomor 51 Tahun 2009.
} 
Walaupun ditentukan wilayah hukum PTUN meliputi wilayah kabupaten/kota, dan wilayah hukum PTTUN meliputi wilayah propinsi, namun saat ini PTUN hanya ada di setiap ibukota provinsi yang wilayah hukumnya meliputi wilayah provinsi, dan PTTUN hanya ada di beberapa ibukota provinsi, yaitu: Medan, Jakarta, Surabaya, dan Makasar, yang wilayah hukumnya masing-masing meliputi beberapa provinsi.

Dalam perkembangannya, sesuai Pasal 9 A UU Nomor 9 tahun 2004 jo UU Nomor 51 Tahun 2009, selain mempunyai wewenang penyelesaian perkara sengketa tata usaha negara, di lingkungan peradilan tata usaha negara dapat diadakan pengadilan khusus dibidang perpajakan yang diatur dengan undang-undang; dan pada pengadilan khusus tersebut dapat diangkat Hakim Ad Hoc untuk memeriksa, mengadili, dan memutus perkara yang memerlukan keahlian dan pengalaman dalam bidang tertentu dan dalam jangka waktu tertentu.

\section{PENUTUP}

Sistem peradilan suatu negara tidak dapat dilepaskan dari sistem hukum yang berlaku di negara tersebut. Dengan kata lain, sistem peradilan suatu negara merupakan sub sistem dari sistem hukum negara tersebut. Oleh karena sistem hukum yang berlaku di Indonesia adalah sistem hukum yang berdasarkan Pancasila dan UUD Negara RI Tahun 1945, maka sistem peradilan di Indonesia juga didasarkan pada nilai-nilai Pancasila dan pasal-pasal yang ada dalam UUD Negara RI Tahun 1945.

Berdasarkan Pasal 24 ayat (2) UUD Negara RI Tahun 1945 (hasil Amandemen Ketiga Tahun 2001) ditentukan bahwa: "Kekuasaan kehakiman dilakukan oleh sebuah Mahkamah Agung dan badan peradilan yang berada di bawahnya dalam lingkungan peradilan umum, lingkungan peradilan agama, lingkungan peradilan militer, lingkungan peradilan tata usaha negara; dan oleh sebuah Mahkamah Konstitusi”.

Keempat lingkungan peradilan di bawah Mahkamah Agung RI, yaitu: peradilan umum, peradilan agama, peradilan militer, dan peradilan tata usaha negara, sebagai subsub sistem peradilan di Indonesia, masing-masing memiliki stuktur kelembagaan, kewenangan, dan hukum acara tersendiri yang berbeda satu dengan yang lainnya sesuai dengan kekhususan dan kompetensi absolut masing-masing yang tidak bisa dicampuradukkan. Walaupun keempat lingkungan peradilan tersebut masing-masing mempunyai kekhususan dan kompetensi yang berbeda dan tidak bisa dicampur-adukkan, namun pada akhirnya keempat lingkungan peradilan tersebut bermuara ke Mahkamah Agung RI sebagai pengadilan negara yang tertinggi yang mengontrol dan mengawasi keempat lingkungan peradilan di bawahnya, baik pengawasan di bidang administrasi, personil, 
keuangan, dan juga penanganan perkara di empat lingkungan peradilan, maupun pengawasan dalam bentuk pemeriksaan perkara kasasi oleh Mahkamah Agung RI.

Berbeda dengan lingkungan peradilan yang lain yang telah menyesuakan dengan perubahan undang-undang kekuasaan kehakiman yang baru, struktur kelembagaan dan kewenangan pengadilan dalam lingkungan peradilan militer yang merupakan bagian dari sistem peradilan di bawah Mahkamah Agung RI, hingga saat ini masih diatur dalam UU Nomor 31 Tahun 1997 tentang Peradilan Militer dan belum disesuaikan dengan UU Nomor 4 Tahun 2004 tentang Kekuasaan Kehakiman, karena Rancangan Perubahan terhadap UU Peradilan Militer yang telah dibahas sejak tahun 2005 hingga sekarang belum disepakati oleh DPR dan Pemerintah. Bahkan ketika UU Peradilan Militer belum dapat disesuaikan dengan UU Nomor 4 Tahun 2004, pada tanggal 29 Oktober 2009 UU Nomor 4 Tahun 2004 telah dicabut dan kemudian diganti dengan UU Nomor 48 Tahun 2009 tentang Kekuasaan Kehakiman yang terbaru. Belum adanya kesepakatan tersebut disebabkan karena adanya perbedaan pendapat yang tajam antara Pemerintah dengan DPR tentang perubahan kompetensi peradilan militer, yang mana DPR menghendaki peradilan militer hanya memeriksa dan mengadili prajurit TNI yang melakukan tindak pidana militer saja, sedangkan Pemerintah menghendaki kewenangan peradilan militer tetap seperti semula, yaitu peradilan militer berwenang memeriksa dan mengadili prajurit TNI yang melakukan tindak pidana, baik tindak pidana umum maupun tindak pidana militer.

Selain mengatur tentang susunan dan kekuasaan pengadilan dalam lingkungan Peradilan Militer, UU Peradilan Militer juga mengatur tentang susunan dan kekuasaan Oditurat Militer, Hukum Acara Pidana Militer, dan Hukum Acara Tata Usaha Militer.

\section{DAFTAR PUSTAKA}

\section{A. Buku-buku :}

Bagir Manan, 2007, Sistem Peradilan Berwibawa (Suatu Pencarian), Mahkamah Agung RI, Jakarta.

Djoko Sarwoko, 2002, Perlindungan HAM Bagi Terdakwa Dalam Proses Persidangan, dalam Mahkamah Agung RI, Kapita Selekta Hak Asasi Manusia, Mahkamah Agung RI, Jakarta.

M. Yahya Harahap, Pembahasan Permasalahan dan Penerapan KUHAP, Pemeriksaan Sidang Pengadilan, Banding, Kasasi, dan Peninjauan Kembali, Edisi Kedua, Cetakan Kesembilan, Sinar Grafika, Jakarta, Oktober 2007.

S.R. Sianturi, 1985, Hukum Pidana Militer di Indonesia, Cetakan Kedua, Alumni AhaemPetehaem, Jakarta. 


\section{B. Undang-undang :}

Undang-Undang Nomor 2/Pnps/1964 tentang Tata Cara Pelaksanaan Pidana Mati Yang Dijatuhkan Oleh Pengadilan Di Lingkungan Peradilan Umum Dan Militer.

Undang-Undang Nomor 8 Tahun 1981 tentang Kitab Undang-Undang Hukum Acara Pidana.

Undang-Undang Nomor 12 Tahun 1995 tentang Pemasyarakatan.

Undang-Undang Nomor 31 Tahun 1997 tentang Peradilan Militer.

UU Nomor 7 Tahun 1989 sebagaimana yang telah diubah dengan UU Nomor 3 Tahun 2006 dan diubah lagi dengan UU Nomor 50 Tahun 2009.

UU Nomor 48 Tahun 2009 tentang Kekuasaan Kehakiman.

Undang-Undang Nomor 49 Tahun 2009 tentang Perubahan Kedua atas Undang- undang Nomor 2 Tahun 1986 tentang Peradilan Umum.

Undang-Undang Nomor 50 Tahun 2009 tentang Perubahan Kedua atas Undang-Undang Nomor 7 Tahun 1989 tentang Peradilan agama.

Undang-Undang Nomor 51 Tahun 2009 tentang Perubahan Kedua atas UU Nomor 5 Tahun 1986 tentang Peradilan Tata Usaha Negara.

Peraturan Pemerintah Nomor 36 Tahun 1959 jo PP Nomot 18 Tahun 1977 jo. PP Nomor 13 Tahun 1983 tentang Peraturan Gaji Anggota Angkatan Bersenjata Republik Indonesia

Keppres RI Nomor 56 Tahun 2004 tentang Pengalihan Organisasi, Administrasi, Dan Finansial Pengadilan Dalam Lingkungan Peradilan Militer Dari Markas Besar TNI Ke Mahkamah Agung RI.

Keputusan Panglima TNI Nomor: Kep/23/VIII/2005

Surat Keputusan Bersama Ketua Mahkamah Agung RI dan Panglima TNI Nomor: KMA/065A/SKB/IX/2004 dan Nomor: Skep/420/IX/2004 tanggal 01 September 2004 tentang Kerja Sama Dalam Pembinaan Personil Militer Bagi Prajurit TNI Yang Bertugas Pada Pengadilan Dalam Lingkungan Peradilan Militer. 